\title{
Psychophysical Approaches and Practices in India: Embodying Processes and States of 'Being-Doing'
}

This essay articulates a South Asian understanding of embodied psychophysical practices and processes with a specific focus on Kerala, India. In addition to consulting relevant Indian texts and contemporary scholarly accounts, it is based upon extensive ethnographic research and practice conducted with actors, dancers, yoga practitioners, and martial artists in Kerala between 1976 and 2003. During 2003 the author conducted extensive interviews with kutiyattam and kathakali actors about how they understand, talk about, and teach acting within their lineages. Phillip Zarrilli is Artistic Director of The Llanarth Group, and is internationally known for training actors in psychophysical processes using Asian martial arts and yoga. He lived in Kerala, India, for seven years between 1976 and 1989 while training in kalarippayattu and kathakali dance-drama. His books include Psychophysical Acting: an Intercultural Approach after Stanislavski, Kathakali DanceDrama: Where Gods and Demons Come to Play, and When the Body Becomes All Eyes. $\mathrm{He}$ is Professor of Performance Practice at Exeter University.

USHA NANGYAR is an accomplished actress/dancer ${ }^{1}$ and teacher within the kutiyattam style of staging Sanskrit dramas whose origins date from the ninth century C.E. Kutiyattam is indigenous to Kerala State, the Malayalam-speaking southwestern coastal region of India. Within the kutiyattam tradition of 'solo acting', one important set piece takes place when an actor playing a specific character visualizes and/or transforms into a different character not present on stage. This process of visualization is known as 'head to foot' (padadikshesham) acting, and can take the form of remembering a lover or seeing a god or goddess.

In 2004, Usha Nangyar was approached by dancer/choreographer, Gitanjali Kolanad for instruction in this unique approach to visualizing and 'becoming' a character. Gitanjali was researching and preparing a new solo performance/adaptation of an Indian folk tale, 'The Flowering Tree', 2 in which Gitanjali plays/dances the role of a sister who, after meditating upon and visualizing the goddess, transforms herself into a tree; when she sought instruction from Usha Nangyar on visualizing and transforming into the goddess. Usha instructed Gitanjali to: breathe through the eyes whenever there is a point of emphasis, as in this solo acting when visualizing the goddess. Close off all other avenues of breath - do not use your nostrils, but inhale/exhale through your eyes. Hold all the orifices closed, and close your ears. It is like 'looking' as in yoga.

Usha Nangyar's instructions here reveal a uniquely South Asian understanding and approach to the inner and outer dimensions of acting. First, Usha provides a very specific set of instructions about what Gitanjali should do psychophysically during this process of visualization and transformation, i.e., whenever there is 'a point of emphasis' she must:

- close off all other avenues of the breath except her eyes, including not breathing through her nose;

- sense throughout her body that all the body's orifices are literally 'closed' including her ears, mouth, nose, and anus/genitals;

- finally and most importantly she must 'breathe' only through her eyes.

But Usha's instructions do much more than simply provide Gita with a description of what she should do physically. Secondly, 


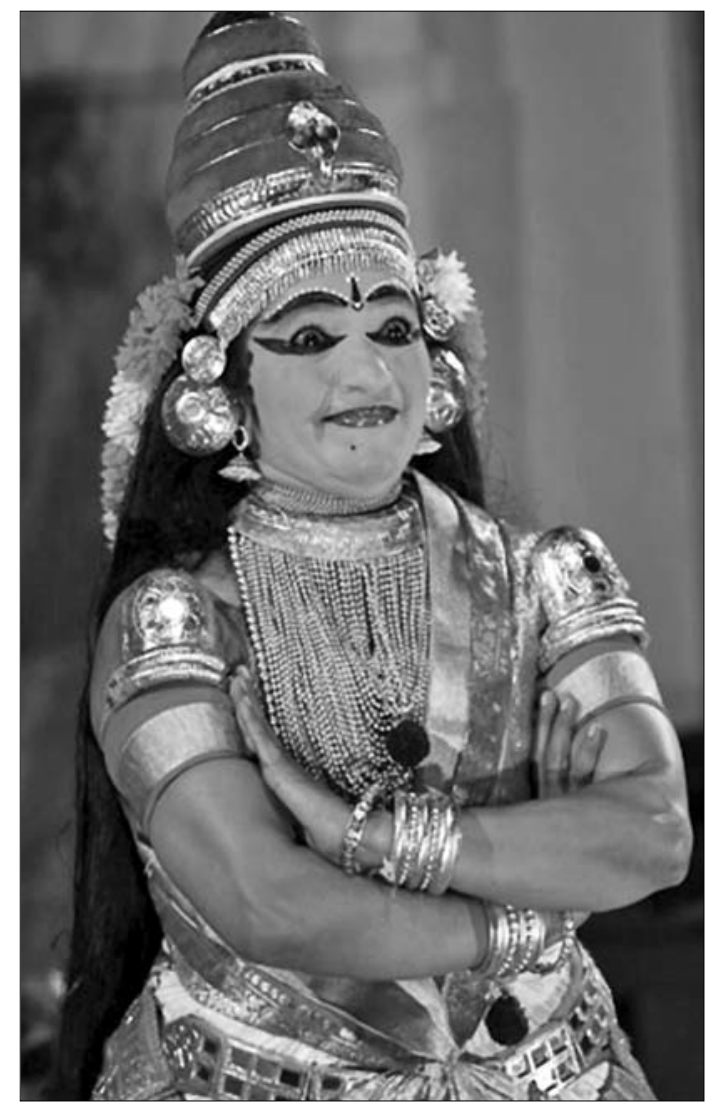

Usha Nangyar in performance.

they simultaneously provide a rich, phenomenologically descriptive account of what the actual process of embodiment is like from the actor's perspective 'inside' the experience of visualization and transformation. Thirdly, Usha's instructions provide a representation of the process of practice per se. This is evident when Usha compares the actor's psychophysical task of 'breathing' through her eyes to "looking" as in yoga'. She is pointing to the fact that the acting process here is psychophysiologically like and therefore parallel to that of a yogi's act of 'looking', and - as explained in detail later - to the fact that both the actor and yogi assume a paradigm or map of the yogic (subtle) body in their acts of 'looking'. To summarize, in her instructions, Usha simultaneously provides Gitanjali with all three of the following: practical instruction, phenomenological description, and a representational model of what she is being asked to do in practice. ${ }^{3}$
This essay provides a further exegesis of Usha's instructions and attempts to answer the following questions that arise:

- What precisely does Usha mean when she says the actor must 'breathe through the eyes'?

- How does the actor/practitioner close off all venues of the breath except the eyes?

- What does it mean to 'close the ears' and 'all the orifices' of the body?

- What do these instructions reveal about a South Asian approach to acting and embodiment? More specifically, what assumptions are
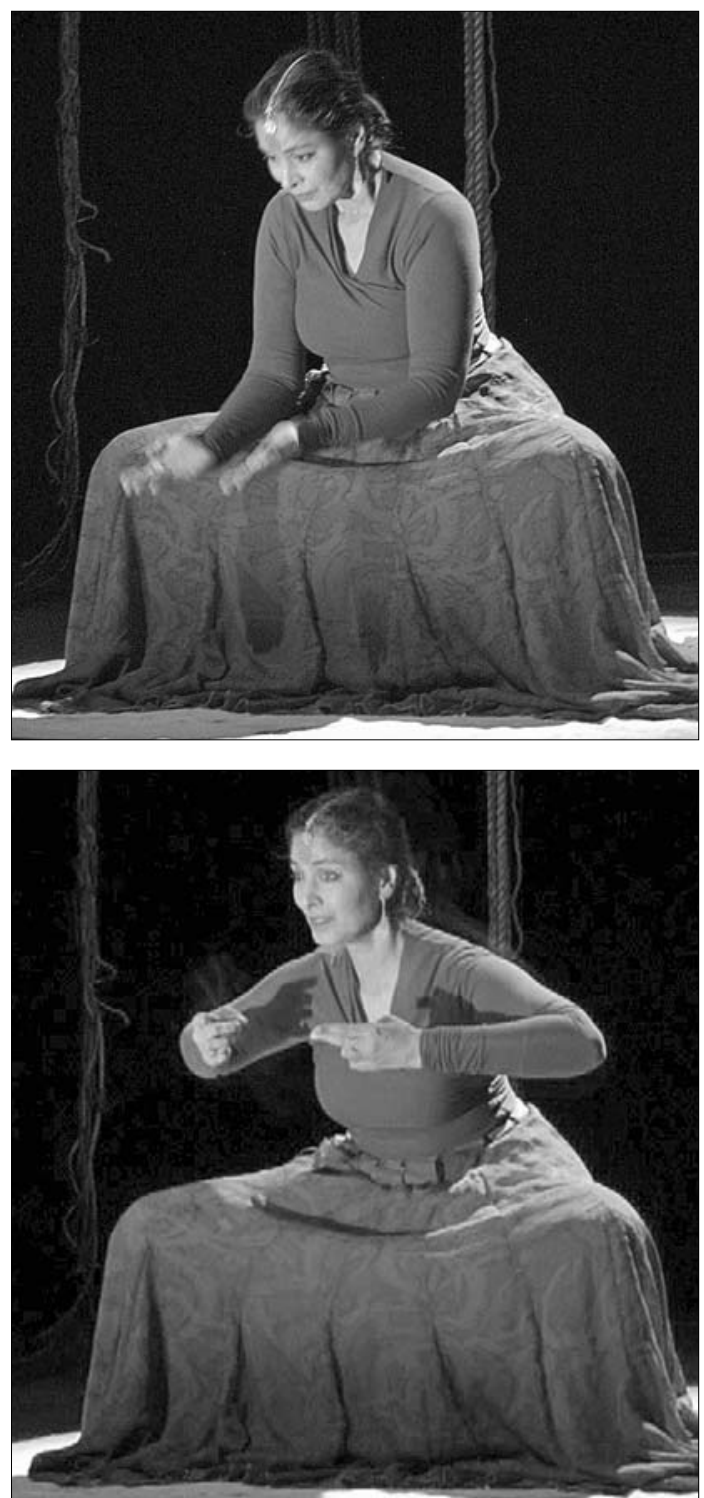

Gitanjali Kolanad in the process of visualization in 'The Flowering Tree'. Photos: Riaz Mehmood. 
made about the inner (psycho) and outer (physical) dimensions of embodied experience, the relationship between inner/outer (the actor's awareness and embodiment), and about the deployment of the actor's awareness and consciousness in the moment of performance?

- How does the practitioner train to become virtuosic in these psychophysical processes?

Kutiyattam. Originally known as kuttu (drama), kutiyattam literally means 'combined' or 'mixed' acting. Kutiyattam is a unique, regional style of staging dramas written in Sanskrit that began to develop from earlier forms of Sanskrit drama under the patronage of King Kulasekharavarmam (978-1036 C.E.) in the southwestern coastal region of India known today as Kerala State. The early history of Sanskrit theatre dates to between the second century B.C.E. and second century C.E. when all aspects of theatrical practice were recorded in the Natyasastra. This encyclopedic collection included information on the mythological origins of drama, types of plays, theatre buildings, music, psychophysical training, how the actor embodies a character's states of being-doing (bhava), etc. It outlines a complete theory of aesthetics (rasa) and explains how pleasure is brought to an audience in performance. The distinctive style of kutiyattam developed very late in the history of Sanskrit theatre at a time when Sanskrit theatre and drama were on the decline elsewhere in India (see Paulose, 2006, p. 65-101). By about the fourteenth century kutiyattam had developed its distinctive style and began to be performed on a regular basis in specially constructed temple theatres within the compounds of high-caste Hindu temples as a 'visual sacrifice' to the primary deity of the temple. The performance tradition has been sustained by the three sets of temple servants who traditionally have the right to train in and perform kutiyattam - Cakyars who play male roles, Nambiars who provide percussion accompaniment on large copper drums (milavu), and Nangyars who play the female roles. The Cakyars and Nangyars are highly learned actors with a vast knowledge of Sanskrit and Malayalam literature. They traditionally enact both solo performances, in which the actor elaborates stories from encyclopedic collections of traditional tales (puranas), and the 'combined acting' of kutiyattam in which they stage selected acts of important plays in the repertory. The example given here exemplifies their approach to solo acting where the actor playing a character elaborates the story by seeing and/or becoming another character in the story.
To answer these complex questions we must expand our discussion beyond kutiyattam per se to examine also: (1) the yogic practices to which Usha refers; (2) what we know about acting and actor training in the early history of Indian theatre when Sanskrit dramas were staged, and (3) other embodied practices unique to Kerala - the martial art, kalarippayattu, ${ }^{4}$ and kathakali dance-drama, which together can present a more complete picture of the techniques, processes, and modes of representation through which an Indian psychophysical paradigm is actualized in practice. Finally, in order to expand our understanding of the importance of this South Asian psychophysical paradigm being discussed, the essay will conclude with a brief overview of how several contemporary Indian practitioners are utilizing elements of this in their contemporary performance practices.

\section{'It is Like "Looking", as in Yoga'}

What did Usha mean by " "looking", as in yoga'? ${ }^{5}$ From his reading of the late Upanishads and the Mahabharata, South Asian scholar David Gordon White gathers descriptions of yogis who, like those to whom Usha refers, have developed special powers. White discusses yogis with the power to leave their bodies via 'rays (rasmi) that radiate outward from their eyes, heart, or fontanel, as a means to rising up to the sun or to entering the bodies of other creatures' (2009, p. 64). As White explains, this phenomenon becomes a commonplace of medieval yogic theory and lore; however, these notions and practices are quite different from 'classical yoga', where the emphasis is on 'turning the senses inward 'to isolate the mind-body complex from distractions of the outside world' (2009, p. 64).

The radiant sun appears to be the divine prototype for all of the epic practitioners who either rise via its rays to their apotheosis or who channel themselves through rays to enter into other people's bodies.

(White, 2009, p. 68)

Theories of perception within a number of different Indian schools of philosophy 
(Mimamsaka, Samkhya, Vedanta, and NyayaVaiseaika) all agreed that 'ordinary (ocular) perception only reaches the "surface" of things' as they come in contact with their objects:

The Nyaya-Vaisesika schools hold that while seat of the visual organ is the eyeball in its socket or the pupil of the eye, visual perception in fact occurs when a ray of light (tejas) emitted by the pupil comes into direct contact, even conforms, with its object, from a distance. ... The perceiving mind or sense organ differs from the sun, whose rays actually penetrate the earth or the bodies of living beings to infuse them with its vivifying energy or to definitively reabsorb their life breaths at death.

(White, 2009, p. 70-1)

Yogi-pratyaksa or Yogi perception designates the extra-ordinary 'powers of vision' that yogis were understood to be able to generate through their practices to 'more closely approximate the divine model of the radiant sun' (White, 2009, p. 68). This model of the yogic power of 'looking' is also part of the ethnographic present.

As discussed in my ethnography of kalarippayattu, in its most esoteric form of martial arts practice those who have developed yogic powers are believed capable of attacking the physical body's 'vital [or death] spots' by simply looking or pointing, i.e., they have attained special powers that enable them, like the rays of the sun, to penetrate into the body of another, and thereby to cause instant death without even touching the vital spots (Zarrilli, 1998, Chapter 5).

White concludes his analysis with the following commentary on this particular model of the Indian yogic body:

Rather than being unidirectional in its extension beyond its visible physical contours, the human body bristles with openings and extensions that are nothing other than the rays of perception that flow out of every sense organ to 'touch and take the measure of every being at every level in the hierarchy of transmigrations', and in the case of the sun, Yogis, Buddhas and gods, to penetrate those beings and transform them as they please... [This particular] yogic body was, and remains, an open system, capable of transacting with every other body - human, divine, and celestial - in the universe.

(2009, p. 74-5)
Kathakali (literally, 'story play') is a genre of dance-drama dating from the late sixteenth century, also indigenous to Kerala. It enacts stories from the two great Indian epics, the Mahabharata and Ramayana, as well as stories about Krishna from the puranas. When kathakali emerged as a new form of dance-drama, its first actors were Nayars - a particular Hindu caste many of whom were practitioners of kalarippayattu. So kathakali's well known intensive system of psychophysical training and massage originated in kalarippayattu. Its aesthetic form, hand gestures, plastic use of facial expression, and understanding of acting were all based upon and influenced by the much earlier techniques and aesthetics of kutiyattam. In both kutiyattam and kathakali easily distinguishable make-up types allow the audience to identify and understand each character. But unlike kutiyattam, where the actors deliver the lines of the Sanskrit text they are performing, in kathakali onstage vocalists deliver the entire dramatic text in a unique form of singing (sopanam). The actordancers speak the entire text with the complete language of hand gestures. (See Zarrilli, 2000.)

Although Usha compares the actor's psychophysical process of 'looking' to that of the yogi, she is of course not suggesting that

Kalarippayattu is a compound technical term that refers to the traditional martial art and physical therapy healing techniques unique to the southwestern coastal region of Kerala, India (the same region in which kutiyattam is found). The first half of the compound term, kalari, refers to the place of training - a five-foot deep earthen pit, covered by thatched palm. The second half of the compound term, payattu, is derived from the Tamil payil meaning 'to become trained, accustomed, practice', and refers to the martial exercises practised in the training space. The kalari was a centre for psychophysical exercise, martial arts training, and physical therapy treatments in villages throughout Kerala. As revealed in India's vast literary traditions, Indian martial arts have existed on the subcontinent since early antiquity. Kalarippayattu as the distinctive Kerala martial art emerged by the twelfth century C.E. out of two earlier source traditions - ancient Tamil martial practices indigenous to the far south of the subcontinent, and the Dhanur Vedic ('science of the bow') brought to the south as part of the Aryan migration from north India (see Zarrilli, 2000, p. 24-60). 
Gitanjali mimetically 'imitate' the yogi, nor is she suggesting that the actor/dancer has obtained the ostensible 'powers' of a yogi as described above. Rather, she is pointing to the fact that both actor and yogi engage in parallel psychophysiological processes. Both assume a common understanding and paradigm of the 'power' to affect another whether it is in the case of the Yogi actually to enter or attack an-other human being, or in the case of the actor to imaginatively materialize another, and/or transform into an-other. The actor's psychophysiological 'looking' is similar in kind, not degree to the accomplished yogi's 'looking'. Both are psychophysiological processes which actualize a relationship of the doer to the done that is actual and material. The yogi operates at a cosmological level, the actor-dancer at an aesthetic level. Both have their own reality effects.

\section{Embodied Modes of Practice in South Asia: Shared Patterns and Assumptions}

To gain a more nuanced understanding of Usha's instructions regarding 'breathing' through the eyes, I turn to the practitioner's relationship to and use of the breath in embodied practices. In a bio-medical sense, it is not possible of course literally to 'breathe' through one's eyes. However, as explained in detail below, in South Asia the term translated as 'breath', prana or prana-vayu, also means 'wind' or 'winds' (whether external in the environment or internal within the body), as well as 'vital energy', i.e., the force of life itself. Prana as the 'wind' or 'vital energy' is therefore an animating force per se, and is not confined to the bio-medical model of the 'breath'.

In South Asia prana is the conceptual and practical link between the gross, outer, physical body and inner experience. For Usha, working through the breath, the kutiyattam actor 'sees' and thereby animates/materializes each specific aspect of the goddess that appears before her - from the goddess's head and hair, all the way down to her feet. In each moment of 'emphasis', as the actor 'breathes through the eyes' she animates a material element of this other.
Likewise, when Gitanjali transforms from the sister into the tree, her breath serves as the psychophysical vehicle through which she (materially) 'becomes' this 'other.' A major aspect of the audience's pleasure in this type of acting is witnessing the actor's embodied visualization and subsequent transformation into the other as it happens.

The centrality of the breath in South Asian modes of embodied practice is reflected in interviews conducted with masters of kalarippayattu and kathakali dance-drama. One martial arts master summed up the importance of controlling the internal 'wind' and developing 'wind power' as follows:

Prana-vayu is the basis of all other powers, and only by increasing one's wind-power will that person's mental power and physical power increase. The various steps, poses, and applications in martial arts practice need strength (balam); however, this strength can only be acquired when one has control of the vital energy. Only by taking the breath in and training it at the root of the navel (nabhi mula) can the practitioner spread the 'special' power situated in the inner parts through the external organs. ${ }^{6}$

Kathakali actor/master teacher Padmanabhan Nayar (1928-2007) makes explicit what is usually implicit:

Anything physical requires control of the vayu. All the arts ... have their own specific ways of using the vayu. In kathakali, each of the inner states of being-doing (bhava) require the specific development and proper use of the vayu. . . . I systematically train the actor in all the body movements for a role, and how to bring the vayu through the whole body. ...

The teacher should know how the vayu moves around within the body for each specific bhava, and then utilize the basic poses and movements of the training which help to train the student in the circulation of the vayu. . . . So you must make the student practice until he is perfect through repetition, and then the vayu will come. I won't stop until the student gets it correctly. The students will get bored, and I too will get bored, but I won't stop until the student gets it correctly!

(Interview, I July 2003)

From the interviews cited thus far, it is clear that like yogis, practitioners of kutiyattam, kalarippayattu, and kathakali assume that learning to awaken, control, and circulate the 
wind/vital energy (vayu) throughout the body is central to mastery in all three arts.

But how does the practitioner learn to awaken and circulate the inner wind in order to become a virtuosic actor/dancer or martial artist? Kathakali actor M. P. Sankaran Namboodiri explained that 'first, perfection of the body is most important' (interview, 1978). Echoing this observation, a Muslim master of kalarippayattu explained how any student 'who wants to become a master must possess complete knowledge of the body'. Therefore, training begins with meyyarappatavu, or 'body-control exercises'. The first step in preparing, perfecting, or gaining complete knowledge of the body is by repetition of the basic exercises and forms that constitute a specific mode of embodied practice.



Two young kathakali performers-in-training demonstrate the kind of body flexibility gained through their psychophysical training process. Pictured is a rehearsal (coliyattam) of the kathakali drama Lavanasuravadham where the two brothers, Lava and Kusa, string their bows in preparation for a fight. Photo: Phillip Zarrilli.

The earliest description we have of this type of training for the actor/dancer is recorded in the Natyasastra (c. second century B.C.E. to second century C.E.). An intensive, rigorous 'method of exercise' involving preparatory psychophysical exercises and complete massage of the body is prescribed as follows:
One should perform exercise ... on the floor as well as (high up) in the air, and should have beforehand one's body massaged with the (seasamum) oil or with barley gruel. The floor is the proper place (lit. 'mother') for exercise. Hence one should resort to the floor, and stretching oneself over it one should take exercise.

(Ghosh, 1967, p. 209)

Traditionally, training began at an early age under the guidance of a master-teacher (guru), and in some traditions students lived in their master's house from childhood. As one masters basic preliminary exercises, the neophyte goes on to learn more advanced techniques - in kutiyattam and kathakali these include learning dance steps/choreography, movement patterns necessary to play various roles in the repertory as well as an entire system of hand-gestures (mudras) and facial gestures (rasa-abhinaya).

Whether learning the preparatory exercises or more advanced techniques, the student mimics the master and/or senior students, repeating over and over each day the basic techniques until they become part of one's body knowledge - ready at hand to be used 'unthinkingly'. For the young sevento ten-year-old going through this type of training, the process is anything but romantic: it is difficult, hard work. Masters are strict, correcting the student in performance of each detail. Over time, this process or repetition has the potential to shape and transform the neophyte into a mature, accomplished, virtuosic practitioner.

Exercises for the body at first appear to simply be physical, i.e., they seem to be 'that which is external'. But as the forms are practised assiduously and as they 'come correct', students begin to manifest physical, mental, and behavioural 'signs' (lakshana) that indicate change and effect a gradual transformation not only of the body, but also of one's relationship to doing the exercises. The exercises gradually become that which is internal' (andarikamayatu). The relationship between the doer and what he does has been qualitatively transformed from an external process that only engages the gross physical body to a psychophysical one in which the practitioner's inner experience, awareness, 
attentiveness, and perception are ideally engaged and altered.

One of the central 'signs' marking this transformation from external form to internal action is when the teacher observes how 'the vayu (wind/energy) comes' fully into a student's practice. In order to understand both this process of transformation of 'the body' as well as what is meant by 'that which is internal', we will briefly examine two key South Asian paradigms that inform psychophysical processes and acting.

When Usha Nangyar compared the process of 'looking' by inhaling/exhaling 'through the eyes' to that of yoga, as discussed earlier, she makes explicit the fact that a yogic paradigm and understanding of embodied experience informs embodied practice throughout South Asia. What Usha does not explicitly mention is the second paradigm of the body and experience that informs training and embodiment throughout South Asia India's traditional system of medicine, Ayurveda (literally, the 'science of life'). Possessing 'complete knowledge of the body' traditionally meant gaining knowledge of three different but closely related 'bodies' of practice:

1. the fluid body of humours and saps;

2. the body composed of bones and muscles (and for the martial arts practitioner the vulnerable vital junctures or spots of the body); and

3. the subtle, interior body.

The first two bodies are based on Ayurveda and together constitute the gross, 'physical/ exterior body' (sthula-sarira). The third - the subtle, interior body (suksma-sarira) - is most explicitly identified with Kundalini/Tantric yoga, but this map of interior experience informs all systems of embodied practice in South Asia.

\section{The ‘Physical/Exterior Body' in Ayurveda}

Since the yogic and Ayurvedic paradigms are ubiquitous in South Asia, informing how 'the body', the 'mind', their relationship, and experience are traditionally understood in yoga, martial arts, and performing arts, we will briefly examine these two paradigms before continuing our discussion of psychophysical acting.

Ayurveda is a compound term literally meaning 'the science' or 'knowledge' of 'life'. It is the indigenous form of medicine that seeks to establish harmony with the environment by maintaining equilibrium in a process of constant fluid exchange. The art of this traditional medical system is meant to establish:

'junctions' or 'articulations' between man and his environment, through the prescription of appropriate diets and regimens. . . E Equality, balance, and congruous articulations are meant for the conservation and restoration of these precious fluids. ... By means of ['restraints'] (brahmacarya) ... and various other psychosomatic disciplines, one should establish congruous junctions with the surrounding landscapes and seasons, and thus one should protect one's powers, one should husband one's vital fluids.

(Zimmermann, 1986, p. 17-18)

The daily practice of psychophysical disciplines is understood to establish congruence among the three humours: wind (vata), phlegm (kapha), and fire (pitta). The role of exercise and massage in maintaining inner fluidity and articulation among the humours was explained in antiquity in a medical text attributed to Susruta:

The act born of effort (ayasa) of the body is called exercise (vyayama). After doing it, one should shampoo (vimrd) [massage] the body on all sides until it gives a comfortable sensation. Growth of the body, radiance, harmonious proportions of the limbs, a kindled (digestive) fire, energy, firmness, lightness, purity (mrja), endurance to fatigue, weariness, thirst, hot and cold, etc., and even a perfect health: this is what is brought by physical exercise. ... It is especially beneficial to him in the winter and spring. But in all seasons, every day, a man seeking his own good should take physical exercise only to half the limit of his strength, as otherwise it kills. When the [wind] vayu hitherto properly located in the heart $(h r d i)$ comes to the mouth of the man practising physical exercise, it is the sign (laksana) of balardha, of his having used half of his strength (Cikitsasthana, xxiv, 38-49).

(Zimmermann, 1986)

To maintain heath, one's diet as well as massage and vigorous exercise should be adapted to the seasonal cycles. Therefore the 
rainy season from June through August is considered the best for intensive psychophysical training and massage. During these cool months the heat produced by vigorous exercise and massage is counterbalanced by the seasonal accumulation of phlegm. By contrast, the very hot summer season from March to the onset of monsoon is characterized by accumulation of the wind humour; therefore exercise should be either cut back or avoided altogether. Exercise and massage are understood to increase the circulation of the wind humour throughout the body, and this, too, counterbalances the accumulation of phlegm during monsoon.

The fluid humoral body is supported by the body as a frame of bones, muscles, ligaments, vessels, joints, as well as their junctures and vital spots. This body must be exercised daily to achieve flexibility and fluidity - a process assisted by massage and application of special oils to the entire body.

\section{The Interior, Subtle Body of Yoga}

The specific term yoga is derived from the Sanskrit root, yuj, meaning 'to yoke or join or fasten . . . make ready, prepare, arrange, fit out . . . accomplish' (Monier-Williams, 1963, p. 855-6). Yoga encompasses any ascetic, meditational, or psychophysiological technique which achieves a 'binding', uniting, or bringing together of the body and mind or consciousness.

The wide variety of yogic pathways developed historically in South Asia included: karma yoga or the law of universal causality; maya yoga or a process of liberating oneself from cosmic illusion; nirvana yoga or a process of growing beyond illusion to attain atonement with absolute reality; and hatha yoga or specific techniques of psycho-physiological practice. The most popular and visible form of yoga practised today are versions of 'classical' hatha yoga whose major source is usually traced to the Hatha-yoga-pradipika ('Illumination of the Yoga of Force') dating somewhere between the thirteenth and eighteenth centuries, and the more modern reformations of 'classical' yoga now being called 'modern postural yoga' (de Michelis,
2005; Mark Singleton, 2010; Doniger, 2011). This yoga includes repetition of breath-control exercises, forms/postures (asana), combined with restraints/constraints on diet and behaviour. These practices are understood to act on both the physical body (sthula sarira) and the subtle body (suksma sarira) most often identified with Kundalini-Tantric yoga.

The physical body and subtle body of yoga are not absolute categories. Exercise of one body is understood naturally to affect the other. They are fluid conceptual and practical counterparts. Specific parts of the subtle body are thought to correspond to specific places in the physical body. These are analogous/homologous correspondences and are never exact. The two are so fundamentally related that what affects one body is understood to affect the other.

As early as the $R g$ Veda (1200 B.C.E.) ascetic practices (tapas) are mentioned. ${ }^{7}$ By the time of the composition of the Upanishads (c. 600-300 B.C.E.), specific methods for experiencing higher states of consciousness and control of the self were well developed. The earliest use of the term 'yoga' is in the Katha Upanisad, where the term means 'the steady control of the senses, which, along with the cessation of mental activity, leads to the supreme state' (Flood, 1996, p. 95).

Philosophical assumptions informing yoga vary widely, and range from monist (all is one) to dualist (all is two) to atomist (all is many). Yoga's psychophysical practices have never been 'confined to any particular sectarian affiliation or social form' (Flood, 1996, p. 94). As a consequence, both yoga philosophy and practices are found throughout South Asia and inform all modes of embodied practice as well as the visual and plastic arts.

From the earliest stages, yoga developed as a practical pathway toward the transformation of both the body and the consciousness (and thereby 'self'). The ultimate goal was spiritual release $(m o k s a)$ through renunciation by withdrawal from the world and the cycles of rebirth. Some yogic pathways provide a systematic attempt to control both the wayward body and the potentially overwhelming senses/emotions that can create 
disequilibrium in daily life. Rigorous practice therefore can lead to a sense of detachment (vairagya) through which the yogin withdraws completely from daily life and its activities, and is understood to achieve a state where he transcends time (kalalita). The yogis and yogic powers discussed at the beginning of this essay reveal a type of yogi oriented towards and open into the world.

Yoga philosophy and its practices have also always informed and been directly adapted by non-renunciants - i.e., those who keep their feet firmly within the spatiotemporal world. Traditionally this included India's martial castes (ksatriyas) who served as rulers and/or those martial artists/warriors in the service of rulers, as well as a wide variety of artists - actors, dancers, musicians, painters, and sculptors.

Rulers, martial artists, and performing/ plastic artists had to live and act very much in and upon the world and/or its social order. Rulers/ksatriyas were required to govern, maintain the cosmic order mirrored in the microcosm of worldly kingdoms, and be able to use well-honed martial skills to maintain order. Artists/performers were expected to bring pleasure and aesthetic joy to the diverse gods of the Hindu pantheon and/or those one was serving and entertaining. Their modes of embodiment are more like the 'open system' discussed by White (2009, p. 74-5).

In contrast to the 'classical' yoga practitioner-as-renunciant who withdraws from everyday life, for martial artists and actor/ dancers especially, 'yogic' practices do not necessarily lead to renunciation and/or disengagement from daily life. Rather, as the practitioner engages in yoga-based psychophysical practices, ideally the ego becomes quiet and the emotions calm. One is better able to 'act' within their respective sociocultural domain while still in the world. The martial or performing artist who practises yoga-based psychophysical techniques does so to transcend personal limitations to better 'act' rather than withdraw from the world. In the South Asian context, later in life, when one's duties and social obligations have been fulfilled, the individual might choose to become a renunciant and follow the radical, ideal pattern of the yogi who withdraws from life.

Of most relevance to our discussion of psychophysical acting is the relationship between the physical and subtle bodies. They are integrally related. The concept and specific inner alchemy of the subtle body historically developed separately from Ayurveda as part of ascetic and yogic practice and appears fully developed after about the eighth century C.E. The essential elements of the subtle body usually identified in these later

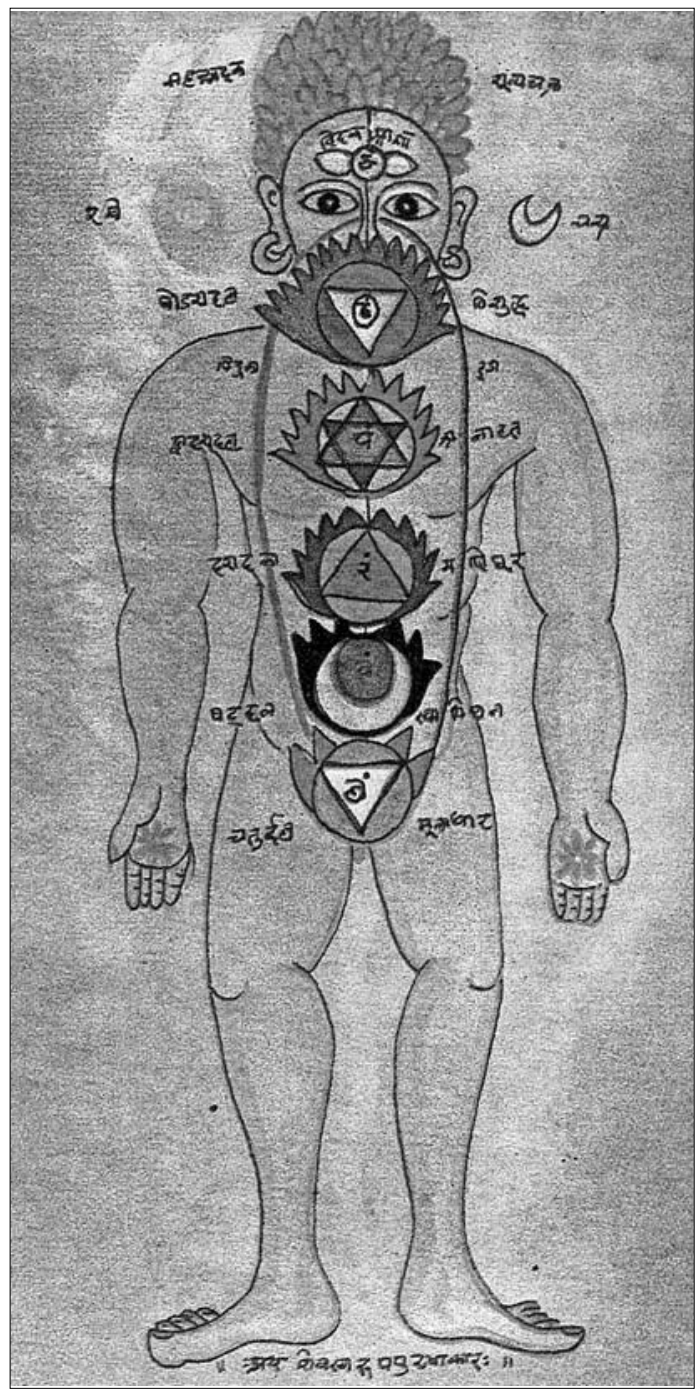

The cosmic energy (kundalini or Sakti) is understood and represented as coiled within the lowest centre, where it sleeps until awakened. Pictured here is one typical 'map' of the subtle body with each of the cakras, arrayed along the spine, represented by a flower. To either side are the two main channels (nadis). 
texts include structural elements known as wheels or centres (cakra), channels (nadi), and dynamic elements including the vital energy or wind (prana, vayu, or prana-vayu) and the cosmic energy (kundalini or Sakti) sleeping coiled within the lowest centre.

Through the channels or conduits (nadi) flows the vital energy or inner wind. The channels usually range in number from ten to fourteen. Of the three most important channels two (ida and pingala) reach from the lower end of the spinal column (muladhra cakra) to the left and right nostrils. Between and intertwined with them is the central channel (susumna-nadi). It too originates at the 'root' of the spinal column and stretches to the top of the head. All the channels originate at the lower end of the spinal column and form an intricate network through the body linking muladhara-cakra with the various limbs and sense organs.

The wheels or centres (cakra) number from five to eight and take the form of a stylized lotus (padma). They are arrayed vertically from the base of the spine (along the corresponding central susumna nadi) up to and through increasingly refined and more subtle centres. These centres are places within the subtle body where latent functions, often represented as half-opened buds, await the invigorating exercise of the internal energy. The number of petals indicates the frequency of vibration once a cakra is activated.

\section{Moving from 'That which is External' to 'That which is Internal'}

The 'breath' or 'vital energy' within is the conceptual and practical link between the physical and subtle bodies of Ayurveda and yoga, and the key to understanding the 'internal'. The natural form that the wind humour took in classical Ayurveda was its form in nature as wind or breath. ${ }^{8}$ Wind is understood to spread throughout the body and to be responsible for all activity, just as atmospheric wind is thought to be responsible for all activities in the natural world. Within the physical body, specific activities are identified with specific forms of wind or breath (see Zarrilli, 2000, p. 131; Filliozat,
1964, p. 210-11; and Flood, 2009). The term prana or prana vayu is used generically to refer to any type of wind activity within the body, whatever its form, as well as to the specific wind/energy/life-force of the breath.

This equation of breath or wind as the vital energy or 'life-force' (jivan) was explained to me by kalarippayattu master teacher Gurukkal Govindankutty Nayar, when he asked rhetorically:

Who am I? My hands, legs, nose, etc.? Who am I? My hands, legs, breast? That, all of these is prana. Just to close your eyes - that is one prana. Yawning is another prana. Therefore, life itself (jivana) is prana.

Another martial arts master explained how prana is :

the vayu which rules the body as a whole. Prana is the controlling power of all parts of the body. Vayu is not just air, but one power (sakti). That is what rules us completely. Prana means jivana 'life', individual soul.

In kutiyattam, kathakali, and kalarippayattu trainings, the vayu is gradually awakened, controlled, and spread throughout the body in one or more of the following three ways:

1. By overt practice of special breath-control exercises as taught by some but not all specific teachers;

2. 'correct' daily practice of preparatory body control exercises such as yoga asanas, or kalarippayattu and kathakali training exercises; and

3. 'correct' practice of other psychophysical forms - such as the circulation of 'vital energy' to enliven hand or facial gestures in kutiyattam and kathakali.

One typical yoga practice is literally to close off all the body's orifices the better to concentrate one's vital energy as well as one's 'mind'. When done fully and 'correctly', psychophysical exercises and forms of embodied practice operate at both the physical level and on a subtle, interior level. The practitioner gradually frees himself from the flux of the body's agitation, and/or the everyday psycho-mental stream of consciousness. The 'interior' affected by psychophysical training includes consciousness, awareness, and perception as they are deployed in doing 
the exercise/form. This process reflects a general cultural assumption that long-term practice of psychophysical disciplines leads to discoveries. Discussing what one learns through yoga practice, the Bhagavad-Gita (4.38) tells us, 'He who attains perfection through the practice of yoga discovers of his own accord, with time, the brahman present in his soul' (Varenne, 1976, p. 58, italics mine). Varenne cites the Amritabindu Upanisad as further illustration of the idea that 'knowledge' in a discipline of embodied practice is assumed to be 'already there', hidden, waiting to be discovered:

And knowledge is hidden in the depth of each individual just as in milk the butter we cannot see is hidden; this is why the wise practitioner must carry out a churning operation within himself, employing his own mind without respite as the churning agent.

(Varenne, 1976, p. 59)

What is meant by the term 'mind' here? In South Asia there are three important Sanskrit terms which can be translated as 'mind'. The term buddhi specifically refers to the rational mind, i.e., such mental processes as judgement, evaluation, inference, deliberation, conducting systematic research, etc. The term mana or manasa may be translated (as in the passage above) as 'mind'; however, it actually means:

both mind and heart, as well as mood, feeling, mental state, memory, desire, attachment, interest, attention, devotion, and decision. These terms do not have a single reference in English, and must be understood through clusters of explicit and implicit meanings.... The terms of emotion and thought, mind and heart are not opposed.

(McDaniel, 1995, p. 43)

Another Sanskrit term, cittam, means thinking, mind, intelligence, will, or heart. When used in relation to martial arts, yoga, or acting, both mana and cittam are understood as consciousness itself - i.e., awareness, perception, or the attunement/direction of one's attention-in-action. Unlike the term buddhi (rational mind), the use of mana or cittam assumes that the 'mental' element engaged in doing a psychophysical practice is not rational thought 'in the head', but an opera- tion of the mind/awareness/consciousnessitself in-the-body as it engages a specific psychophysical task. As Haridas Chaudhuri explains, in yoga-based psychophysical disciplines such as kalarippayattu, kutiyattam, or kathakali,

mind and body are not heterogenous but homogenous. They are different evolutes or modes of manifestation of the same fundamental creative energy. ... In the same way, the outside physical environment and the mind-body evolves from the same primal energy, too. Since there is homogenous and existential continuity here, the fact of interaction between mind and matter causes no problem. The dualism of mind and body is a product of our discursive understanding. It is a division inserted by dichotomous thinking within the continuum of our multidimensional experience.

(Chaudhuri, 1977, p. 255-6)



In practice of kalarippayattu, the leg should become so flexible that it can be easily kicked so that it touches the hand. Pictured is Sathyan Narayanan Nayar of the CVN Kalari, Thirvananthapuram, executing the first leg exercise. 


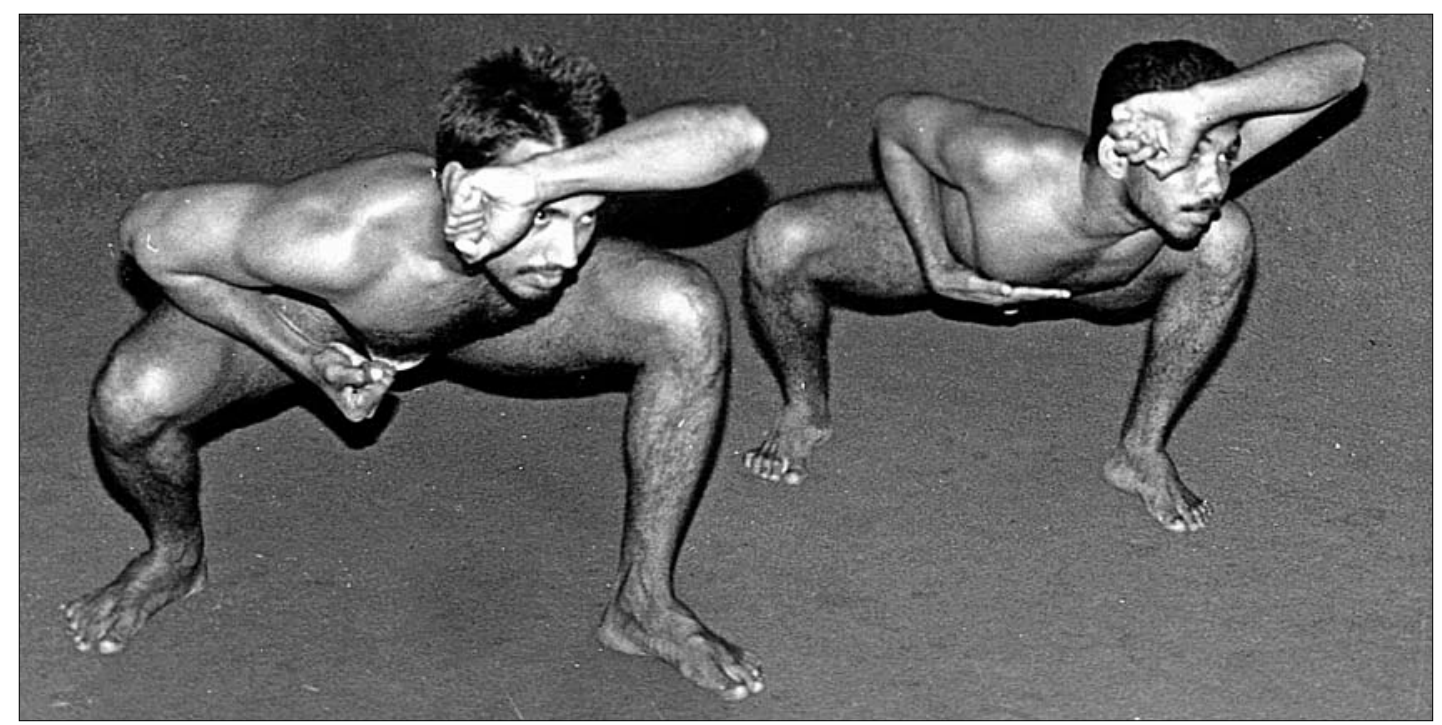

Two students of the kalarippayattu master, Sreejayan Gurukkal, execute the deep tanjamppayattu steps.

The goal of all virtuosic psychophysical systems is reaching a state of masterly 'accomplishment' (siddhi) in which the doer and done are one. At the highest level, a master's practice seems 'effortless'. The practitioner reaches a state of being/doing within which one is free to practise the principle of nonaction in action' - i.e., one is in a position to practice 'I act, yet it is not I but Being acts through me' (Chaudhuri, 1977, p. 252). This is a self-actualized mode of realization that is (ideally) egoless in its action. The dancer is danced; the song sings the vocal artist; the kalarippayattu practitioner's body is so flexible that it 'flows like a river'; the kutiyattam actress materializes the other as she is visualized and transformed. The yogi is freed for meditation; the martial artist is freed to fight; the actor/dancer is freed to 'become'.

The actor enters into an optimal relationship with an action, i.e., the relationship is one of unmediated, fully embodied being/ doing. The actor does and/or apprehends in each present moment. In performance, the actor 'is that' which he does. As one kathakali actor explained, the actor 'becomes one with the character' ('natan kathapathravumai tadatmyam prapikanam') in a psychophysical sense. ${ }^{9}$

One way of understanding this optimal state of awareness and actualization in acting is through a key passage in Nandikesvara's
Abhinayadarpanam - a Sanskrit text usually dated somewhere between the tenth and thirteenth centuries. The passage describes the optimal state of being/doing from the actor/performer's perspective. It explains how the actor realizes India's rasa/bhava aesthetic in performance:

Where the hand [is], there [is] the eye; Where the eye [is], there [is] the mind; Where the mind [is], there [is] the bhava; Where the bhava [is], there is the rasa.

From the actor's point of view 'inside' a performance, the ideal state of awareness one inhabits is a non-conditional state of being/doing. The use of the state-of-being verb ('is') clearly indicates that there is no intentionality or conditionality in this optimal state. It is an emergent state - wherever the actor's attention (eye) is directed, the actor's mind/heart/awareness is fully present. With the actor's mind/heart/awareness fully present in the moment, the actor embodies the state of being/doing (bhava) specific to the dramatic context in each moment. Simultaneously, when the actor is fully present embodying a specific bhava, then the audience will experience aesthetic bliss (rasa).

Drawing upon principles of yoga, the Indian actor's body is traditionally trained 


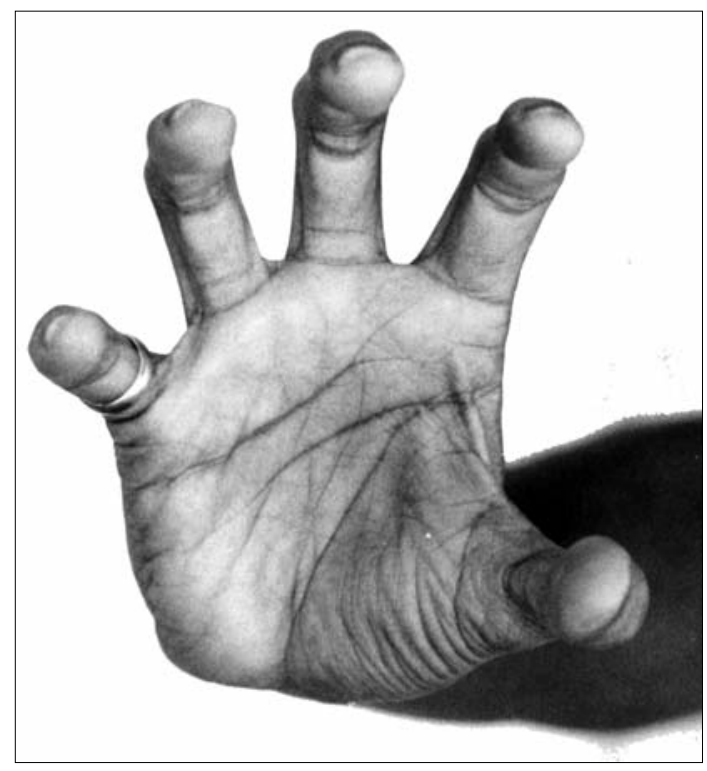

Above: one of kathakali's twenty-four root handgestures (mudras) - urnanabha. Note how the palm and fingers are energetically animated/activated.

Below: one of kathakali's nine basic facial gestures (rasaabhinaya). Pictured is fury, anger, or wrath (krodha bhava). Here the 'wind' is pushed into the lower eyelids. Photos: Phillip Zarrilli.

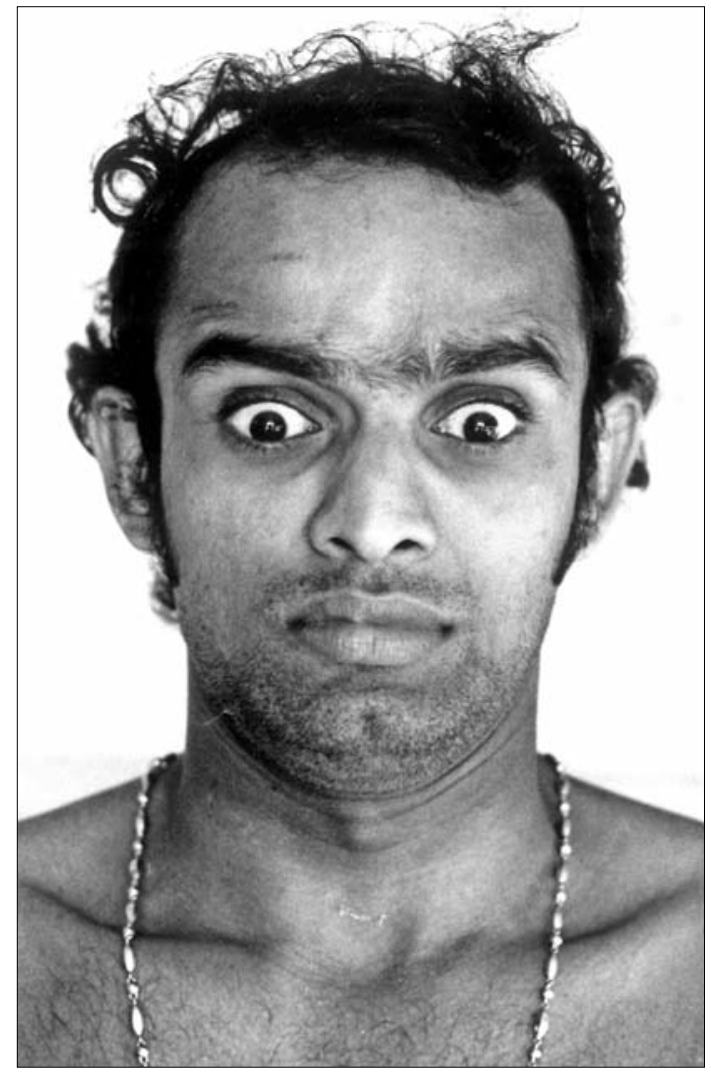

through a long-term process to become a suitable vehicle through which this ideal aesthetic experience might be actualized. Conventions guiding acting and movement ranged from lokadharmi - the 'ordinary' and 'concrete' - to natyadharmi - that which is 'extraordinary' and 'ideational'. The 'concrete' is what is easily recognizable, such as a gesture mimetically representing a deer. The 'ideational' is that which is elaborated, abstracted, transformed, or distilled and therefore more decorative, abstract, and stylized. As genres of performance, kutiyattam and kathakali both possess 'ordinary/concrete' and 'extraordinary/ideational' aspects in similar but different proportions

More specifically to understand psychophysical acting process in India, we examine in detail the kathakali actor's training and approach to actualizing 'the interior' when acting/dancing roles within the kathakali repertoire.

\section{The Psychophysical Actor at Work in Kathakali Dance-Drama}

Intensive training of the kathakali actor/ dancer traditionally began from the age of seven or eight. (Today's students may be ten or much older.) Formal instruction is a long and arduous process that lasts eight hours a day, six days a week, for between six and ten years. When their formal training is complete, young actors at first dance preliminary dances and/or play minor roles and only gradually work their way into medium-sized and major roles. It is generally agreed that kathakali actors usually do not reach maturity as performers until about the age of forty.

The formal years of training are understood gradually to reshape the actor's bodymind. Basic techniques must first be mastered, including preliminary body preparation exercises and massage, meticulous isolation exercises for the eyes and facial muscles/ facial mask, a complete vocabulary of hand gestures (mudras) and facial expressions (rasaabhinaya), rhythmic patterns, and set dance steps and choreography.

All these elements are woven into the fabric of a complete performance of a dance- 
drama text. ${ }^{10}$ In addition, the young student must grow and mature as an individual, engage in study and reflection of the dramatic texts and the collections of stories and epics on the basis of which specific dramatic texts have been authored, develop his imagination, and integrate all these into shaping and playing small, medium-sized, and large roles in the repertory.

The specific techniques of training, as well as the application of those techniques to playing roles combine to render the entire body flexible, balanced, and controlled. Over time these techniques help the individual to awaken, discover, and creatively embody and utilize the inner 'wind/breath/life-force' (prana, prana-vayu) in performance.

\section{Preliminary Body Preparation and Exercise}

With the onset of the cool, seasonal monsoonal rains, beginning as well as advanced kathakali students start their annual cycle of training by undergoing the same process of 'body preparation' ${ }^{11}$ Based on Kerala's martial art, kalarippayattu, daily training begins with the repetition of a rigorous physical regime of body-control exercises and oil massage given with the teacher's feet and hands. ${ }^{12}$ Together the exercise and massage gradually render the body flexible, balanced, controlled, and reshaped to suit kathakali's aesthetic style and stance - a grounded, wide stance with splayed knees and full turn-out, arched back, use of the outsides of the feet, and upturned big toes. After applying oil to his entire body, the student pays respects with his body to Lord Ganesha - the elephant-headed incarnation of Lord Vishnu who is prayed to before any new undertaking - by prostrating himself on the floor. He then performs a series of jumps (cattam) as well as jumping steps, and finally progresses through an elaborate series of body-control exercises.

Either before or immediately following massage, additional exercises are performed including the splits (suci, literally meaning 'needles'), circling the body, body-flips, and footwork patterns (kalsadhakam). Another essential part of the early morning training regime designed to develop a young actor's expressivity is repetition of eye exercises (kannusadhakam) performed in nine different directions and three different speeds.

\section{Eye Exercises (kannusadhakam)}

Students sit cross-legged on mats with a lengthened spine and focus their gaze directly ahead. The instructor sits in front of the students. The student places the thumb of each hand gently on the lower lid, and the index finger lifts the upper lid. The teacher traces patterns with his index finger in nine patterns as the student keeps his focus on the teacher's finger. The geometrical designs pass through nine different points and include straight lines up and down and on the horizontal plane, diagonals, circles, and figure eights. Each pattern is taught in slow, medium, and fast speeds.

The most obvious expressive means through which the actor conveys a character's states of being/doing (bhava) within the dramatic context of a story include not only the eyes, but hand gestures and facial expressions. Therefore, the young actor must technically master both modes. This means exercising the fingers, wrists, and hands, as well as the sets of facial muscles (cheeks, lips, etc.) required fully to embody each expressive state.

Kathakali's language of gesture and expressive use of the eyes is part of its inheritance from the Natyasastra via kutiyattam. Both kathakali and kutiyattam base their gesture language of twenty-four root mudras on a regional text, the Hastalaksanadipika - a catalogue of basic hand poses with lists of words which each pose represents (see Prekumar, 1948; Venu, 1984; Richmond, 1999). The two terms, mudra and hasta, refer to the twenty-four root gestures performed with a single hand, combined hands, or mixed hands. Meanings are only created when the actors use the basic alphabet literally to 'speak' with their hands.

The kathakali actor's face is a pliant vehicle for displaying the constantly shifting manifestations of a character's inner states of being/doing (bhava) through which he serves as a vehicle for the audience's aesthetic 


\section{Rasa-Bhava Aesthetic Theory}

The Natyasastra clearly establishes the rasabhava aesthetic as the central theoretical and practical organizational concept for theatre when it states, 'Nothing has meaning in drama except through rasa.' The actor's task is fully to realize and embody states of being-doing (bhava) as the vehicle through which aesthetic experience is provided for spectators. Rasa is so called 'because it is capable of being tasted' (Ghosh, 1967, p. 105). The analogy of rasa as the tasting or savouring of a meal is offered to explain the process by which a theatrical performance of a play attains its own coherence.

'The "taste" of the various ingredients of a meal is both their common ground and organizes them as its end' (Gerow, 1981, p. 230). What the actors bring towards the audience, and offer as the 'meal' to be tasted, is each character's states of being/ doing (bhava) specific to the ever-shifting dramatic context of the drama. The accompanying rasas are made available for 'tasting' as each bhava is embodied and elaborated in performance.

The Natyasastra identified eight permanent states of being/doing (sthayibhava). Each of the various states or moods arises from the actor's process of embodiment as they play characters in the drama, as well as the process of aesthetic perception per se. Playwrights and composers structured their work around those modes most useful to the elaboration of the dramatic context. In this sense, the 'seed' of the rasa experience is implicit in a drama, and made explicit by the actors as they perform. In the rather simple one-act farce The Hermit/Harlot, the Prologue as well as the play proper elaborate the comic (hasya rasa). In performance, the expressive form(s) that 'the comic' takes and the audience response varies within the context of the drama per se. Here is what the Natyasastra has to say about the expression of the comic (hasya):

'This is created by ... showing unseemly dress or ornament, impudence, greediness, quarrel, defective limb, use of irrelevant words, mentioning different faults, [etc.] The result is represented] by consequents like the throbbing of lips, the nose, and the cheek, opening the eyes wide or contracting them, perspiration, colour of the face, and taking hold of the sides.' (Ghosh, 1967, p. 172.)

In the first part of the passage, the text lists how to create a comic situation. In the second part of the passage, the text discusses the psychophysical embodiment of the 'comic' state of being-doing.

It is important to differentiate between the aesthetic experience of 'emotion' and everyday emotion. While the basis for the permanent states of being-doing embodied by actors are the ways we react 'emotionally' in everyday situations being attracted by someone or something, or becoming angry, or guffawing while we hold our sides with laughter - these 'everyday' emotions are not the same as the aesthetic experience of rasa. The Natyasastra focuses on how to evoke this aesthetic experience of rasa in the audience. experience of rasa. The nine basic states include: the erotic, love, or pleasure; the comic, mirthful, or derision; the pathetic/sadness; fury, anger or terrible; repulsive or disgust; the wondrous or marvellous; and peace or at-onement.

At first, each expression is learned through continuous repetition and correction. Begin-

\section{The nine basic bhavas/rasas and their facial expressions}

bhava

(states of being/doing the actor embodies)

1. pleasure or delight (rati) corresponds to

2. laughter or humour (hasa)

3. sorrow or pain (soka)

4. anger (krodha)

5. heroism or courage (utsaha)

6. fear (bhaya)

7. disgust (jugupsa)

8. wonder (vismaya)

9. at-onement (sama)

\section{rasa}

('tasted' by the audience)

the erotic (srngara)

the comic (hasya)

pathos/compassion (karuna)

the furious (raudra)

the heroic/valorous (vira)

the terrible (bhayanaka)

the odious (bibhatsa)

the marvellous (adbhuta)

at-onement/peace (santa)*

*The twelfth-century commentator Abhinavagupta identified this ninth state of at-onement/peace. 
ning instruction in how to assume the basic facial expression for rati bhava - the erotic, love, or pleasure - is usually very technical, much like the following:

Open the upper lids as wide as possible. Keep the lower lids slightly closed. With the lips make a soft, relaxed smile, but do not show the teeth. Keep the gaze focused straight ahead. Having assumed this position, begin to flutter the eyebrows. Keeping the shoulders still, and using the neck/head, move the head first to the right, and then to the left - back and forth. While keeping the external focus fixed ahead on one point, move the head to a 45-degree angle to the right, continuing to flutter the eyebrows. Repeat to the left.

Similar instructions for assuming the comic or mirthful (hasa bhava) are as follows:

Slightly raise the upper bridge of the nose between the eyebrows and slightly turn down the outsides of the eyebrows. Keep the eyelids slightly closed, and the lips drawn down on each side. Indent the upper lip muscles on the outsides.

Vasu Pisarody explains how at first many students simply 'move [their] facial muscles'. It is only after six to ten years of training that a 'fuller understanding of the states of expression' arises through the training as well as further reading and personal experience. Eventually the student 'realizes what he had done at first [i.e., simply moving his facial muscles] ... wasn't enough' (interview, 1993).

\section{The Subtler, 'Inner' Art of Kathakali Acting}

As students progress through the training process, a subtler process of 'internal' connection is gradually realized. Each hand gesture 'spoken' and each state of beingdoing embodied is enlivened/animated through circulation of the breath (prana-vayu) - that inner energy or life-force assumed to be present and channelled for emphasis into specific gestures, facial expressions, through the eyes or lower eyelids, etc. There is the external form - the appropriate use of the hands and/or engagement of the facial mask - and the internal dynamic that animates each 'form' - the enlivening action of the prana-vayu.
At the periphery of his awareness, the mature kathakali actor senses or feels the form as it is animated and takes shape. He fully embodies the erotic state with his entire bodymind. He is that state of being/doing at the moment it is brought to actualization. Actualizing 'free' circulation of the vital energy (prana-vayu) within allows the practitioner to release and shape this 'energy' dynamically for the performance of each nuance of a role. As the vital energy circulates within and is shaped through training exercises and performance techniques, there is the 'felt' experiential quality to the flow of prana-vayu throughout the entire body (palms, feet, top of the head, etc.).

Optimally, the kathakali actor attains a state in which his bodymind is fully and constantly 'energized' as/when he moves. For example, when performing the erotic state (rati bhava) the actor animates his external facial mask via this specific breathing pattern:

Beginning with a long, slow, and sustained inbreath, the eyebrows move slowly up and down. The eyelids are held open halfway on a quick catch-breath, and when the object of pleasure or love is seen (a lotus flower, one's lover, etc.), the eyelids quickly open wide on an in-breath, as the corners of the mouth are pulled up and back, responding to the object of pleasure.

(Author's description)

Throughout this process the breathing is deep and connected through the entire bodymind via the root of the navel (nabhi mula); that is, it is not shallow chest breathing, nor is the activity of the breath only in the face. The characteristic breath pattern associated with the erotic sentiment is slow, long, sustained in-breaths with which the object of love, pleasure, or admiration is literally taken in: that is, the sight, form, etc. of the beloved or a beautiful lotus flower is 'breathed in'. This dynamic and intricate process is exemplified in Usha Nangyar's instructions to Gitanjali about how psychophysiologically to take in the goddess she sees before her with/through her breath.

The amount of force brought into the direction and circulation of the vayu depends on the specific state of being-doing actual- 
ized. For the erotic sentiment, much less overt force is given to the breath than, for example, when actualizing 'fury' and sending the breath/wind into the lower lids. Each expressive state has its own unique pattern and strength in use and circulation of vayu.

Students are instructed to breathe only through their nose, and not the mouth - a simple instruction which, when adhered to along with maintenance of correct spinal alignment when performing a variety of exercises, develops breathing which originates at the root of the navel. Correct instruction also comes from the hands-on manipulation of the student's body by the teacher. As kathakali teacher M. P. Sankaran Namboodiri explains,

Without a verbal word of instruction the teacher may, by pointing to or pressing certain parts of the body, make the student understand where the breath/energy should be held or released.

When a student assumes kathakali's basic position with the feet planted firmly apart, toes gripping the earth, it creates a dynamic set of internally felt oppositional forces as the energy is pushed down from the navel through the feet/toes into the earth, while it simultaneously pushes up through the spine/ torso, thereby supporting and enlivening the upper body, face, hands/arms.

This centred groundedness is behind all aspects of kathakali performance including delivery of elaborate hand-gestures. Psychophysiologically, each gesture originates in the region of the root of the navel (nabhi mula) as the breath/energy extends outward through the gesture, optimally giving it full expressivity appropriate to the dramatic moment. ${ }^{13}$ When teaching some of the basic facial expressions, some teachers instruct students literally to 'push the breath/energy' from the root of the navel into a certain part of the face. When creating the furious sentiment (krodha bhava) the teacher may ask the student to push the vayu into the lower lids in order to create the psychophysiologically dynamic quality necessary to actualize 'fury'.

During the 2003 interview with Padmanabhan Nayar, he demonstrated and explained some of the myriad ways in which the vayu is present throughout the body of the kathakali actor-dancer, and how it moves through and supports the actor's embodiment and delivery of all aspects of performance, including the hand gestures (mudras) and facial expressions. Taking the basic stance of the kathakali actor/dancer learned at the beginning of training - the feet are just beyond shoulder width, knees are splayed, and the feet turned on to the outside with the big toes pointing up - Padmanabhan Nayar explained how, in order to sustain this position correctly, the actor/dancer must engage the vayu in four places:

1. through the four toes (except the big toe) as they 'grip' the floor;

2. the knees as they open wide to the sides;

3. the small of the back which is constantly lengthened and flat and on the opposite side of the body, the 'root of the navel' (nabhi mula);

4. and the neck as the chin is tucked in.

'The vayu should never be held in the chest as that will push the chest forward and shoulders back.' From this basic foot parallel position, the vayu sustains the left foot as it slides across the body and extends upward with the big toe extended.

Padmanabhan Nayar also described how proper awakening and circulation of the breath is developed in the fundamental training of the kathakali actor/dancer through the repetition of the beginning body exercises (meyyurappadavu). For example,

You must be doing jumps (cattam) twenty-five times. But when you finish these twenty-five, the student should not open his mouth, but be breathing only through his nose. Through exercises like this, correct use of the vayu will come.

As we talked, Padmanabhan Nayar demonstrated how, when embodying the lotus flower, the actor's fingers open as the petals. Here the 'actor should bring the vayu into the fingers as the petals so that the vibration of the petals is there'.

According to Padmanabhan Nayar, the result of the presence of such a deep, yogic, psychophysical connection through the vayu is that the actor becomes a 'musician inside'. He then 'plays' the psychophysical score of 
each role. Just as the original sounding of the Sanskrit aum is understood to 'vibrate' the universe, so ideally at a micro-level within the actor, when vayu is 'correctly' circulated and fills out the external expressive form, there will be an inner 'vibration' which moves within the actor. So if the actor plays the 'right note inside, then the bhava comes out from the inside... Then only will the movement be according to the character.'

The process of the kathakali actor begins not with the personal, the behavioural, or the motivational aspect of playing an action, but rather with the psychophysiological forms through which the 'emotional' is eventually expressed as the student grows and matures. The student actor's personal feelings are not the point of origin for the creation of a facial or hand-gesture, or for the full realization of a state of being-doing; however, one's experience of life and imagination are used to fill out the outer forms. As he enters the process of embodying the hand-gesture for lotus, the kathakali actor momentarily 'becomes' a lotus flower as he 'sees' its beauty, and 'smells' its fragrance. He 'is' that - i.e., the flower itself as well as the appreciation of the beauty and fragrance of the flower. Constantly in the background is the actor's 'real-life' pleasure encountering the beauty and fragrance of the lotus.

Some teachers also prompt their young students to engage their imagination in specific ways. K. Kanan Nayar explains how he asked his students when practising the heroic state to:

Imagine an elephant. For the erotic state, a lotus. For the furious, imagine a lion. For wonder, imagine a sudden action. I then ask them later in training if they are, for instance, performing wonder, imagine being in a big city. Or imagine being in a forest, seeing elephants, snakes, etc.

(Interview, 1976)

Vasu Pisharody asks his students to 'show the feelings of an experience he can understand'. Vembayam Appukoothan Pillai explains the actor's expression of bhava as

how we feel toward a person or thing. For example, srngara is the emotion we feel towards a thing or a person we like. When we see this person or thing, our mind is enlarged. Similarly, for hasya, it is the feeling we get when we see a funny thing. Sorrow is the feeling we have when we experience difficulties, etc.

(Interview, 1993)

Along with the circulation of the inner wind, engaging the young actor's imagination, perceiving consciousness, or 'mind' contributes to the full embodiment of each expressive state.

Each moment the kathakali actor uses to create a character is always shaped by what is considered 'appropriate to the action'. The performer's engagement in this process is part of an aesthetic that is culturally shaped and identified as 'acting'. Therefore, the actor's engagement in his work is clearly differentiated from both the experience of emotion in everyday life, and from other activities such as that of the ritual performer who enters a state of trance or possession. Trance/possession are a different type of work and experience from that of the actor.

As one actor explained when differentiating between everyday experience and his work as an actor:

It is not right to have real tears on stage: it does not fit our stylized type of theatre. But the emotion of crying must be there and it will affect the audience. As an actor you must always use your emotions, knowing that you are onstage. There must be balance. After the long period of training, the gestures, the technique become automatic. You don't have to concentrate on them; then you can really fill in the role, add the emotion, and so on.

Enacting an aesthetic state of being/doing in kathakali is a fully physicalized and embodied psychophysiological task which ideally engages the actor's bodymind completely.

\section{The Kathakali Actor in Performance: King Rugmamgada's Law}

Kathakali's dramatization of stories from the puranas and epics place at centre stage a variety of idealized but usually flawed epic heroes. One heroic figure is King Rugmamgada. In King Rugmamgada's Law (Rugmamgada Caritam) the playwright Mandavalapalli Ittiraricha Menon (c. 1747-94) dramatized a test of the King's devotion to Lord Vishnu. ${ }^{14}$ 


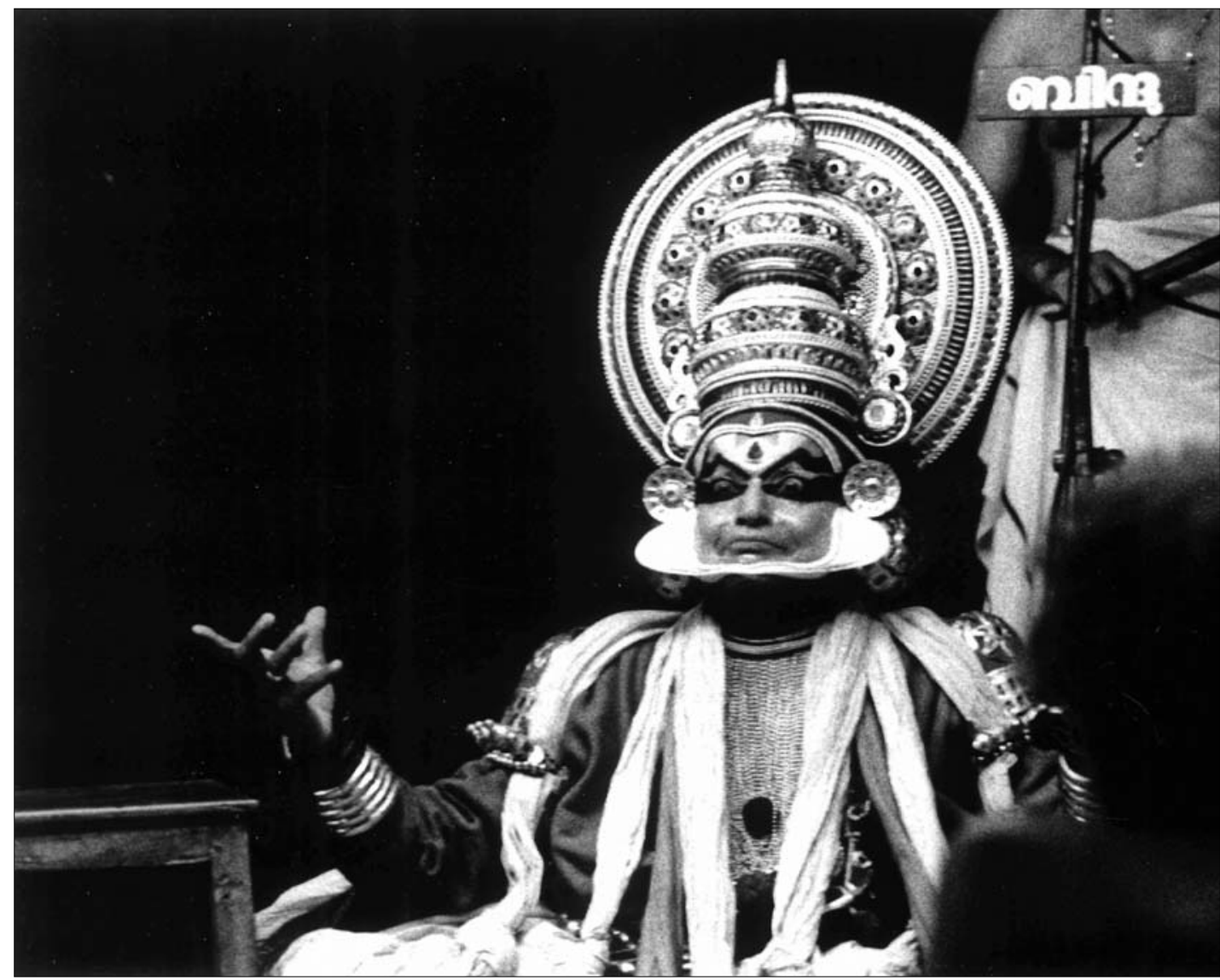

Kalamandalam Gopi Asan in a performance of Rugmamgada Caritam. Above: Rugmamgada sits in a state of disbelief over what has been asked of him. Opposite: loosening his hair, Rugamagada enters a transformative state of 'fury' in which he will be able to sacrifice his son as required. Photos: Phillip Zarrilli.

The full text has ten scenes, but today only the final three (8 to 10) are performed..$^{15}$ The play focuses on how a holy day of fasting and meditation known as ekadasi became central to worship of Lord Vishnu. On ekadasi devotees of Vishnu are supposed to remain pure and chaste while fasting and meditating.

The three scenes usually performed today begin when Brahma - along with Siva and Vishnu, one of the three main gods in the Hindu pantheon - sends the enchantress Mohini to test King Rugmamgada's devotion to Vishnu by having Mohini obstruct his observation of ekadasi. When Mohini first arrives at Rugmamgada's court, he does not know that she has been sent by Brahma to test him. When he sees Mohini, he immediately falls in love with her, and invites her to join his court as one of his consorts. (As was typical in the distant past, along with consorts King Rugmamgada had a primary wife to whom a son, Dharmamgada, and heir to the throne was born.) Mohini agrees, but on condition that he never deny her anything she desires. Rugmamgada agrees by taking an oath that he will indeed never deny her anything she desires.

In Scene 10 of the play, it is ekadasi day. After undergoing the necessary purificatory rites, King Rugmamgada is seated onstage meditating on Vishnu. Mohini enters in an amorous mood, dances, and then addresses Rugmamgada as follows:

\section{O my lover,}

one whose body is as handsome as Kama, one as deep as the ocean,

one who resembles Kama in amorous games, please come to me with delight! 


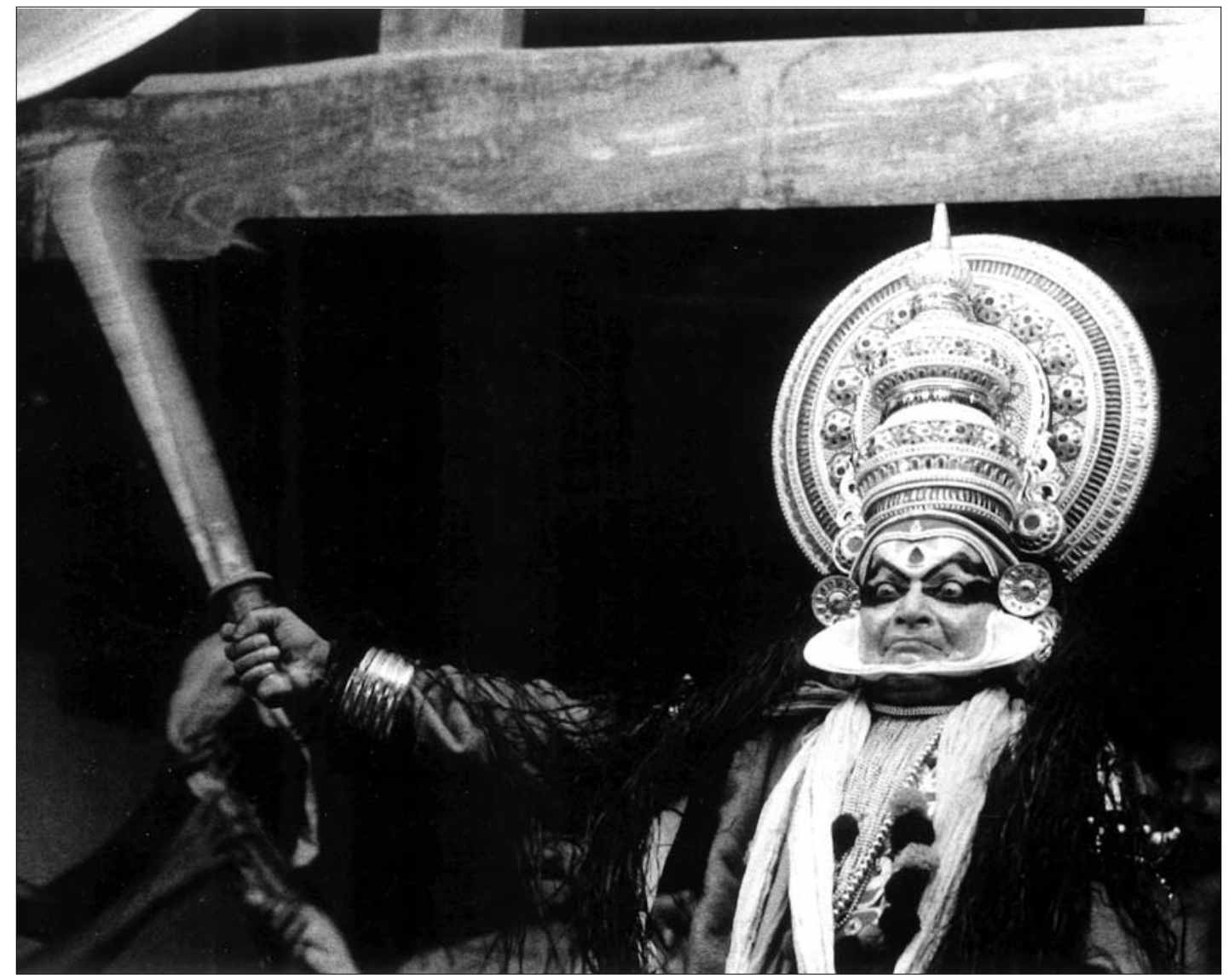

(Today) I haven't yet had the slightest gratification from love play.

As Mohini is about to touch him, Rugmamgada draws away from her, explaining how

O young lady,

I will do everything you desire, (but) today is the auspicious ekadasi day.

All Kama's sports are prohibited.

O young lady, my life-blood, my life-blood.

O auspicious one, (today one) must avoid rich foods,

Oiling the body, and other pleasures.

(One) should only meditate on Vishnu.

(Zarrilli, 2000, p. 164)

Mohini insists on being pleased, but Rugmamgada resists. She asks him, as a King, whether it is 'proper to break a vow like this?' For a King to break any vow would mean his failure to 'uphold the truth' and therefore uphold the world on which his truthfulness is founded.
Rugmamgada continues to refuse, insisting that he must complete his day of fasting and meditation. Mohini is adamant, but offers Rugmamgada a way out of his dilemma:

You may observe this great rite if you meet one condition:

Place your son, Dharmamgada, on his mother's lap and gracefully cut (his neck) with your sword.

King Rugmamgada is shocked, and becomes angry.

Alas! O wicked one! How can you make such hideous demands?

Give up such cruelty and state what you want.

Mohini responds:

If both father and mother freely do (as I have asked) without

Shedding a single tear, then you may observe (the rites) without hindrance.

(Zarrilli, 2000, p. 165) 
King Rugmamgada's test of devotion to Vishnu means that he has no choice but to cut off his son's head as Mohini demands. The climactic, highly emotional scene ${ }^{16}$ of the play in production is one in which the senior actor playing the role of the King enacts his inner conflict between three emotions: anger at Mohini for her demand to cut off his son's head; pathos at the potential loss of his only son and heir to the throne; and the heroic recognition that he cannot transgress a vow he has taken, i.e., as a King he must uphold the truth by cutting off his son's head. Throughout the scene his heroic duty is represented by the sword he holds in his hand - a symbol of his power and authority.

Kathakali's approach to psychophysical acting is clearly and simply demonstrated when a master actor, such as Kalamandalam Gopi, plays the role of Rugmamgada in this scene. The dramatic and performative focus is on Rugmamgada's mental state of torment - an excruciating rollercoaster ride as the King attempts over and again to eradicate both the 'fear' he has at having to execute his duty and the tremendous 'pathos' he feels over the forthcoming death of his son at his own hand. Rugmamgada attempts to summon up the heroic courage necessary to do his duty. As a King, he must erase this personal 'fear' and anguish, and regain the mental equilibrium and 'mental power' necessary to sacrifice his son.

But just as he raises the sword and is about to 'cut the boy's neck and maintain the good fame of our dynasty', he loses his inner resolve when he sees the boy lying on his mother's lap before him, drops the sword, and falls to the ground, fainting. This is anything but 'heroic' behaviour; however, it makes tremendous (melo)drama.

Desperate, Rugmamgada turns to Lord Vishnu, and demands that Vishnu provide him with the 'courage to sacrifice my son, thus protecting the truth, in order to maintain the good fame of our dynasty'. For kathakali connoisseurs in the audience, this particular moment in the performance is the highlight, when the actor sequentially enacts in quick succession the three conflicting states of being/doing which have produced Rug- mamgada's mental confusion and inability to act. The actor moves deftly from a full, psychophysical embodiment of anger as he gazes, eyes blazing, at Mohini, to pathos as he looks at his son, to the heroic as he looks to and takes courage from his sword. Each of these immediate changes from one 'emotional' state to another is achieved through the circulation/manipulation of the vayu - that which fully animates/activates the actor's bodymind.

Finally, in a moment of realization of what is demanded of him in the moment to fulfil his overriding duty, Rugmamgada leans forward, loosening his long hair, and draws its strands to either side of his head. As he raises himself up, Rugmamgada's eyes are wide open, revealing the fact that he has now entered a fourth state of being/doing - 'fury' (raudra). In this transformative state, he has transcended his personal emotional confusion and reached a state beyond fear in which he will be able to cut off his son's head. It is only in this state that he can announce:

I have no fear. What you see with your naked eye is perishable. The truth is the only thing that is imperishable. Therefore, now what should I do? Cut the boy's neck and protect the truth itself!

(Zarrilli, 2000, p. 168)

In this transformed state, just as the King lifts his sword to 'sacrifice' his son as required, Vishnu intervenes and reveals to Rugmamgada the fact that Lord Brahma had sent Mohini to test his devotion.

Returning to Usha Nangyar's instructions to Gitanjali with which we began this essay, it should by now be clear what Usha meant for the actor to 'breathe through the eyes'. By undergoing extensive, in-depth psychophysical training, the inner breath/wind/animating energy is circulated throughout the actor's body and allows the actor fully to inhabit and embody each state of beingdoing - such as Rugmamgada's transformative state of 'fury'. As we have seen, this is especially manifest in the actor's use of his eyes and facial expressions even as the actor's entire bodymind fully engages each expressive state. In Usha's instructions to Gitanjali, 'breathing through the eyes' when- 
ever there is a moment of emphasis allows the actor to concentrate all one's animating energy and power into those psychophysiological moments of materialization of another in the processes of visualization and materialization.

\section{Psychophysical Acting in Contemporary Indian Performance}

In the final part of this essay, I will briefly examine psychophysical acting in contemporary Indian performance. During the nineteenth century the British brought Western drama and theatrical practices such as use of the proscenium stage to India along with English education and financial/industrial practices. ${ }^{17}$ The arrival of English drama in India was part of the expansion of the British empire via the activities of the British East India Company - at first in the three cities where the Company established its bases, i.e., Kolkata (Calcutta), Mumbai (Bombay), and Chennai (Madras). The earliest theatrical activity was by the British for the British.

By the mid- to late nineteenth century English plays were being translated into Indian languages and Indian-language dramas were written and performed by amateur Indian actors for Indian audiences. But as Erin Mee explains:

The spread of English drama was part of colonizing Indian culture; it was designed not only to shape artistic activity but to impose on Indians a way of understanding and operating in the world and to assert colonial cultural superiority.

(2008, p. 1)

In response to colonization, from the late nineteenth through the mid-twentieth centuries there ensued a lengthy period of political struggle for social reform and Indian independence (achieved in 1947). Throughout this period Indian reformers wrote and produced a wide variety of modern textbased dramas that promoted social and/or political reform and even revolution. ${ }^{18}$ The use of drama techniques for social reform and educational purposes has remained an extremely important part of contemporary theatre practice in India to the present. ${ }^{19}$

\section{A Return to Indigenous Indian Models and Psychophysical Practices}

The models for the vast majority of the very early Indian plays and productions were Western; therefore, processes of acting were usually not informed by the types of indigenous Indian psychophysical principles and techniques discussed earlier. Indeed, during the late nineteenth and very early twentieth centuries many of the traditional genres of Indian performance were looked down upon by English-educated Indians. Western sports were preferred over indigenous practices such as yoga. In contrast to Western models of text-based spoken drama, kathakali was sometimes called a 'dumb-show'.

This began to change in the postindependence period when - in response to the dominance of Western models of drama, theatrical practice, and aesthetics - a number of Indian theatre artists began to search for indigenous paradigms, techniques, and subjects that could create distinctively 'Indian' modes of contemporary theatre. As Erin Mee reports in her book-length study of this movement, Theatre of Roots: Redirecting the Modern Indian Stage, these impulses

became known as the theatre of roots movement a post-independence effort to decolonize the aesthetics of modern Indian thatre by challenging the visual practices, performer-spectator relationships, dramaturgical structures and aesthetic goals of colonial performance.

(2008, p. 5)

Three of the most important figures in this movement were the playwright/actor, Girish Karnad (b. 1938) of Matheran, near Mumbai, the playwright/director, Kavalam Narayana Panikkar (b. 1928) of Kerala, and Ratan Thiyam (b. 1948) of Manipur. ${ }^{20}$

Girish Karnad's seminal dramas such as Hayavadana (1971), Nagamandala (1988), and Agni Mattu Male (The Fire and the Rain, 1994) drew upon elements of Western drama, but intermingled with Indian structure, form, content, and aesthetic considerations. The main plot in Hayavadana was drawn from an eleventh-century collection of Sanskrit stories, The Ocean of Stories (Katharsarisagara), but intermingled elements from Thomas Mann's 
The Transposed Heads and of Karanataka's Yaksagana performance tradition. He was creating 'a hybrid theatre that reflects the complex subjectivities of post-Independence reality' (Mee, 2008, p. 142).

When Kavalam Panikkar began working in theatre he wanted to create a theatre that was a distinctively Indian form of 'visual poetry (drishya kavya) - poetry for the eyes as well as the ears' (Mee, 2001, p. 6; Brian Singleton, 1999). For inspiration he turned to Sanskrit theatre and drama and numerous indigenous Kerala performance traditions that he had experienced since childhood vocal music (chanting of the Vedas and the unique Sopanam style of singing), and the psychophysical techniques and systems discussed earlier (kalarippayattu, kathakali, and kutiyattam, as well as Mohiniattam, Kerala's dance tradition performed by women.

When he established his own company, Sopanam, Panikkar wanted his actors to be fully trained in sarirabhinaya - acting with/ through their entire bodies; therefore, early in the company's history, he had members of the company train in kalarippayattu with Gurukkal Govindankutty Nayar of the CVN Kalari, Thiruvananthapuram. ${ }^{21}$

A second highly visible and important contemporary theatre director to have made extensive use of indigenous regional traditions in creating his unique theatre aesthetic is Ratan Thiyam of Manipur. When he established his co-operative ensemble - the Chorus Repertory Theatre - Thiyam began to make extensive use of a variety of distinctive local Meitei arts to train his acting ensemble - traditional forms of dance (Pungcholum and Raslila), storytelling (Wari leeba), and the martial art, thang-ta. Similar to the way in which kalarippayattu provides a complete training of the individual's bodymind, thang-ta practitioners 'learn to activate and use each and every body part' as they simultaneously develop an 'inner awareness' in which they constantly adjust and readjust 'energy and body movement . . . rather than sight' (Mee, 2008, p. 256).

The rediscovery of the value of indigenous Indian psychophysical principles of embodiment through traditional systems of training led India's major actor training institutions such as the National School of Drama in New Delhi (founded in 1959 by Ebrahim Alkazi) and the Calicut School of Drama (Trissur, Kerala) to introduce both traditional genres of performance (kathakali, yaksagana, kutiyattam) and/or practice of yoga and martial arts like kalarippayattu into their curricula alongside Western modes of acting, voice, and movement training. ${ }^{22}$

However, too often there has not been an attempt to integrate the elements and principles of these disparate practices into a clear, practical, and coherent methodology through which acting students may understand precisely how to apply what they are learning to specific dramaturgies, whether Indian, Western, or hybrid. ${ }^{23}$

The 'roots' movement has not been restricted to contemporary theatre practice. Among contemporary Indian choreographers, Chandralekha (1928-2006) was the first major dancer/choreographer to utilize yoga and kalarippayattu training as she reinvented bharatanatyam - the 'classical' form of dance practised in the South Indian state of Tamil $\mathrm{Nadu}$ - for the contemporary proscenium stage. Chandralekha began to take into her company young men who were accomplished kalarippayattu practitioners. Given their years of training in kalaripayattu, they were easily assimilated into Chandralekha's company and choreography - some of which used kalarippayattu sequences such as the salutation with the body known as vanakkam as part of the choreography. When the kalarippayattu practitioners joined Chandralekha's company the entire group began to use yoga and kalarippayattu as their basic psychophysical training. ${ }^{24}$

\section{Performers Trained in Traditional Psychophysical Disciplines}

In the final section of this essay, I turn my attention to recent developments. Rather than focus on institutions and companies, I look at a younger generation of individual actors, dancers, and performance makers who have been trained in depth in traditional psychophysical disciplines such as 
bharatanatyam, kathakali, etc., but whose artistry and performance vocabulary have expanded beyond the traditional genres.

Arguably the best known among internationally recognized theatre actors who originally trained in a traditional performing art before becoming a well-known contemporary stage actor is Yoshi Oida - a long-time member of Peter Brook's company based in Paris, and now an independent theatre director/actor. Yoshi's earliest training was in Japanese kyogen with Okura-san. It is clear from Yoshi's books how central his understanding of the techniques and aesthetics of kyogen and noh are to his understanding of acting processes (Oida with Marshall, 1997, 1992).

This 'younger' generation of Indian performers began their training during the 1970s and 1980s. They have brought the elements, principles, and techniques of their traditional psychophysical trainings into an encounter with alternative, new forms of theatre and performance. For example, Navtej Johar originally trained as a bharatanatyam dancer at Rukmini Arundale's, Kalakshetra (Chennai), and with Leela Samson at the Shriram Bharatiya Kala Kendra (New Delhi). Johar is also a long-time student and practitioner of yoga, having trained in Patanjali yoga at the Krishnamacharya Yoga Mandiram (Chennai), under the guidance of Sri T. K. V. Desikachar. He began teaching yoga in 1985 and in his teaching today freely merges yoga postures (asana), breathing exercises (pranayama), visualization, meditation, and Vedic chanting.

As a dancer Johar has performed at venues throughout the world, and has worked with a number of well-known international companies and choreographers The Bill T. Jones/Arnie Zane Company, the Chandralekha Group, Yoshiko Chuma, and the New York City Opera, among many others. Johar's choreographic work includes solo and ensemble works - 'classical' bharatanatyam as well as contemporary performance pieces, street theatre, performance instalations, site-specific events, musicals, and spectacles. One particularly striking piece of solo performance is 'Never Failed Me Yet'
(1999), which clearly made use of Johar's extraordinary ability to inhabit both inner and outer worlds of performance.

As a final example I will discuss the work of Maya Krishna Rao who creates her contemporary work out of her years of training and performance of kathakali, her interaction with a wide variety of contemporary approaches to performance-making, and most recently her encounters with new media. Trained from a young age at the International Centre for Kathakali in New Delhi, Maya Rao learned kathakali from such excellent traditional masters as Guru Madhava Panikkar who came to the New Delhi Centre on its creation in 1960 (see Zarrilli, 1984, p. 304-8). These master teachers introduced Maya Rao to kathakali not through the female roles, but rather through training her in the strong male roles, providing her with a firm foundation in the 'strong' (tandava) aspects of playing kathakali characters. Only later in her training did she begin to learn, and discover the joys of, the repertory's female roles. Throughout her years of performance and teaching, often at the National School of Drama in New Delhi, Maya Rao's work has been inspired by and based on her kathakali training.

One example of her creative application of her psychophysical training in kathakali to her contemporary performance work is her solo performance, Khol Do, first performed in 1993, and inspired by the short story by Saadat Hasan Manto. In a programme note Maya Rao explains the context which led to her adaptation of the story for performance:

Khol Do is set in the riots that ended the division of India and the creation of a new state, Pakistan. Millions left their homes to cross the new border to make a new home. Sirajuddin was one such who left India and travelled by train to Lahore [in what became Pakistan]. By the time he got off, he was nearly unconscious. For days he sat on the platform staring at the dusky sky. Where was his daughter Sakina? When had he got parted from her? He could only remember the running crowd and Sakina's dupatta, or veil, falling to the ground. When he turned to pick it up she had urged, yelling in the melee, 'Don't bother with it.' In the refugee camp, the heavily armed eight young male volunteers had been solicitous. 'If Sakina is alive 
we will find her for you,' they had said reassuringly. How was old Sirajuddin to know they had already found her but they were not through with her, yet?

(Rao, 1999)

While inspired by this story, Maya Rao's performance - the first of a series of solo performances she began to create in 1993 - is neither an exercise in storytelling nor a kathakali-style enactment of the story. In this sense it is not kathakali per se. In an interview she explains how she has been

looking for a physical language where every action may set off different signals of experience. The eventual form is not kathakali, yet is inspired by it.

(Interview, 1999)

Maya Rao's performance is an hour-long unrelenting, forcefully embodied physicalization that communicates through her bodymind the complete and unrelenting pathos and terror of the experience of dislocation. It is not a literal telling of this horrific story, but rather a suggestive/performative embodiment of elements that communicates the violence and horror of this experience.

As part of Khol Do, Maya Rao occasionally uses specific kathakali gestures, facial expressions, and choreographic elements, but these are woven into the fabric of this totally psychophysical performance score developed out of a lengthy process of improvisation and devising. During the creative process of devising the performance, Maya Rao

kept trying physical actions to generate that range of thought and emotions that are part of the atmosphere of the story. The result is, single gestures may have no particular meaning, but resonances that create multiple meanings.

(Rao, 1999)

At the core of her creative process are kathakali's interior modes of acting - the total engagement of her bodymind through the breath/energy in physicalization of specific states/tasks/actions. Her process is one intended to discover how 'to shift dance energy to a moment in a person's life when words are not being used to signal the tradition' (Rao, 1999) - an approach to creation that is psychophysical, not psychological.
Khal Do was created by Rao as a member of the theatre group Vismaya. Founded in 1993 under the chairpersonship of the late Shri P. N. Haksar, Vismaya draws upon India's diverse traditions of dance, music, literature, and the other arts to create new forms of theatre, using the arts as a means of education. The company's work has increasingly incorporated elements of live camera feed and multi-media design by Amitesh Grover. Their productions include Rainmaker, Departures, A Deep Fried Jam, The Four Wheel Drive, and, most recently, Lady Macbeth Revisited, performed in its most recent version as part of the 2010 Bharat Rang Mahotsav Festival, New Delhi.

During rehearsals for this, kathakali encountered Shakespeare in the form of the demon-king, Ravana. As Rao explains in a programme note,

Ravana entered ... probably to meet his kindred spirit, Lady M. Yes, in many ways these two seem alike - both, often, have very little notion of the consequences of their actions. And so, to honour both, I have used a sequence of mudras and the music with it from a celebrated Ravana piece of a kathakali play. They seemed just right for Lady Macbeth as well.

(2010, p. 157)

What is significant about Rao's work is that 'even though she does not use the code of kathakali, she is clearly influenced by the principles of the form' (2010, p. 156), and the deep, intensive psychophysical engagement in acting process which is produced by years of kathakali training. In Rao's new forms of artistry, kathakali is constantly present, but remains completely in the background. This subtle use of kathakali points to how such traditional modes of psychophysical training provide the individual actor/performer with a process that addresses simultaneously both the subtle, interior processes of working with 'energy' as it 'fills out' each action in a performance score, and the ability to design and shape a performance score through use of the entire body.

The diverse body of work being created today by traditionally trained contemporary performers such as Johar and Rao is helping to change the complexion of the Indian 
performance scene. Crucially for such performers, they have spent a significant period of time immersing themselves in one or more traditional modes of psychophysical training, and these have provided them with a solid foundation for their own ever-evolving creative work..$^{25}$

\section{Notes}

1. From the earliest period of the development of Sanskrit theatre and drama in India B.C.E., performers were equally skilled as actors and dancers.

2. Gitanjali Kolanad is a well known bharatanatyam dancer-choreographer who trained at Kalakshetra in Chennai. She and the author were researching, adapting, and co-creating a new solo bharatanatyam dance theatre performance based on A. K. Ramanujan's translation of the traditional tale, 'The Flowering Tree'. The performance premiered in Chennai and Toronto in 2004.

3. Here 'theory' as a representational model is already thoroughly embedded within and made explicit within the practice per se. In When the Body Becomes All Eyes . . . , my 1998 ethnography of kalarippayattu, I articulated an analytical framework for understanding the relationship between embodied practices and the discourses/representations through which such practices are transmitted. See also Gavin Flood's recent analysis in which a similar framework is articulated (2009).

4. Similar to other Asian cultures, the martial arts of South Asia were historically diverse and regionally specific. I focus here on kalarippayattu of Kerala. Other extant Indian martial arts still practised today include thang-ta (Manipur); ati-tata (also known as ati-murai, varma-ati, and - incorrectly - as 'southern-style kalarippayattu') and silambam (both Tamil Nadu); and Indian wrestling (throughout North India).

5. The yoga discussed here is not the yoga that most people perform in contemporary yoga classes. Some elements of this more popular yoga are discussed later in the essay.

6. This master requested anonymity.

7. For further information on the contested history and diversity of yoga practices and philosophy see Flood (1996, p. 75-102), Varenne (1976), Filliozat (1991), Feuerstein (1980), and White's exhaustive study of siddha yoga traditions in medieval India (1996). Two important recent studies of the reinvention of what is now often called 'modern postural yoga' which has become so popular in the West are de Michelis (2005), and Mark Singleton's controversial Yoga Body (2010). See also Doniger's balanced review of Singleton (2011).

8. Filliozat traces both the organic sense of breath and the association between wind and breath from the period of the Vedas through the classical Ayurveda of Susruta and Caraka and the psychophysiology of yoga. As early as the Vedas breath (prana) and wind (vayu or vata, from Indo-Iranian pre-history the principle of

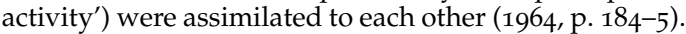
The technical vocabulary of the Vedic texts was later developed into a full 'system of pneumatic cosmophysiology' in which the animating power of wind took the shape of breath or Atman (ibid., p. 65-6). The
Atharvaveda affirmed the identity of breath and wind: 'it is the wind which is called the breath; it is on the breath that all that was and all this is, all is based' (ibid., p. 64-5).

9. A fundamental assumption of Indian thought is the Upanishadic statement, tat tvam asi, 'you are that' (Chandogya Upanisad 6.1 6, p. 12-13). Indian philosophy, cosmology, and everyday life are played out against the underlying assumption that one might 'become one with'. Rather than dualities, it reflects the fact that microcosm and macrocosm, self and universe, subject and object are not set against one another, but are correlative.

10. See Zarrilli (2000) for a complete account of kathakali dance-drama texts and translations of four plays from the repertory.

11. For a complete description of the exercises and training summarized here, see Zarrilli, 1984, p. 107-43.

12. When kathakali began to emerge as a distinctive genre of performance in Kerala under the patronage of rulers of small principalities, its first performers were Nayars trained in the traditional Kerala martial art, kalarippayattu. These kalarippayattu-trained Nayars were pledged to serve their ruler/patron. At first their annual training would have simply been the traditional, rigorous kalarippayattu training. As different styles of kathakali developed, the training evolved from kalarippayattu's preliminary body-training into a distinctive form of kathakali training based on the earlier kalarippayattu. (For further information see Zarrilli, 2000, p. 19ff).

13. This deep, inner, psychophysiological connection to the 'root of the navel' (nabhi mula) is a commonplace assumption in kalarippayattu practice. As Mohammedunni Gurukkal explained about the performance of breath exercises, when performed correctly, 'Your mind is simply on what you are doing. There is a grip or power at the base of the navel (nabhi mula) at the full point of inhalation.' During vigorous practice, sustained breathing is maintained so that there is a constant 'gripping' (piduttam) which comes naturally to the lower abdomen. This is where the traditional loin cloth ( $k a c c a ;$ lengoti) is securely wrapped and tied to 'hold in' the life force.

14. See Zarrilli, 2000, Chapter 8, p. 159-74, for a translation of King Rugmamgada's Law and for more detailed commentary. The play is based on the story of King Rugmamgada found in Chapter 21 of the Padma Purana.

15. Many plays still in the active repertory have been 'edited' to shorten them to three- or four-hour performances. It is commonplace for an all-night performance today to include three shortened plays focusing on scenes of most interest to connoisseurs. Since 1930, when the best-known Malayali poet, Mahakavi Vallathol Narayana Menon, founded the now wellknown Kerala State Arts School (Kerala Kalamandalam), kathakali has been adapted both by practitioners from within the tradition and by artists and entrepreneurs from without. These experiments have included kathakali for tourist audiences, writing and staging new plays based on traditional epic/puranic sources, transforming kathakali techniques and choreography into modern forms of Indian stage dance and/or dancedrama, and writing and staging new plays based on non-traditional sources and/or current events, such as the 1987 leftist production of People's Victory, which pitted the personified hero (World Conscience) against the personified villain (Imperialism). Non-Hindu myths or non-Indian plays such as the stories of Mary Magdalene, the Buddha, and Faust, as well as the Iliad and 
King Lear, have also been adapted for kathakali-style productions.

16. This scene is actually a performative 'interpolation' or elaboration on the dramatic text invented by kathakali actors at some point in the history of the play's production. What distinguishes such interpolations from the original dramatic text is that they are not sung, but simply enacted without repetition by the actor or actors, through action and hand gestures.

17. It is beyond the scope of this essay to provide a complete history of the emergence of contemporary Indian theatre. See Chatterjee (2007), Dharwadkar (2005), Mee (2008), Solomon (1994, 2004), and Chapter 12 in Richmond, Swann, and Zarrilli (1990). For a diverse collection of contemporary Indian plays in English translation, see Mee (2001).

18. For one historical example see Zarrilli (2006, p. 391-9) and Bhaasi, T. (1996).

19. For two of many examples see Eugene Van Erven (1992, p. 114-39) and Zachariah and Sooryamoorthy about the work of Kerala Sastra Sahitya Parishad (KSSP) which uses drama as one of its primary tools for education (1994).

20. Mee provides detailed information in a chapter about the practices of Panikkar (Chapter 2), Karnad (Chapter 3), and Thiyam (Chapter 5) in the context of the 'roots' movement. On Panikkar see also Singleton (1999).

21. The author regularly trained and practised kalarippayattu with Sopanam actors at the CVN Kalari during the 1980s.

22. While Ebrahim Alkazi was still Director of the National School of Drama during the 1970s, the author introduced students and staff at the NSD to kalarippayatt $u$ and its potential for training contemporary actors.

23. See my Psychophysical Acting (2009) for a booklength discussion of these issues and one attempt at integration. Psychophysical Acting provides an overview of how the principles discussed here have informed my own approach to training contemporary actors.

24. For a book-length account of Chandralekha's life and choreography, see Bharucha (1995).

25. Yet another model is that provided by Sajeev Purushothama Kurup. Kurup originally trained for six years as a kathakali dance-drama actor-dancer. After several years of professional performance experience in Kerala within the kathakali tradition, he decided to seek out new forms of training so that he could expand beyond traditional kathakali and enter into contemporary performance practice. Sajeev was admitted to the Theatre Training Research Programme in Singapore and undertook an intensive three-year professional actortraining programme which combines traditional Asian psychophysical disciplines of training (jingxi, noh, wayang won, kutiyattam) with contemporary Western approaches to acting, movement, and voice.

\section{References}

Bhaasi, T., Memories in Hiding, trans. J. George and P. B. Zarrilli. Calcutta: Seagull, 1996.

Bharucha, Rustom, Chandralekha: Woman Dance Resistance. New Delhi: Indus, 1995.

Chatterjee, Sudipto, The Colonial Staged: Theatre in Colonial Calcutta. Calcutta: Seagull Books, 2007.

Chaudhuri, Harisas, 'Yoga Psychology', in Transpersonal Psychologies, ed., Charles T. Tart. New York: Harper and Row, 1977, p. 231-80. de Michelis, Elizabeth, A History of Modern Yoga: Patanjali and Western Esotericism. London: Continuum, 2005.

Dharwadker, Aparna Bhargava, Theatres of Independence: Drama, Theory, and Urban Performance in India since 1947. Iowa City: University of Iowa Press, 2005.

Doniger, Wendy, 'Assume the Position', Times Literary Supplement, 4 March 2011, p. 10-11.

Feuerstein, Georg, The Philosophy of Classical Yoga. Manchester: Manchester University Press, 1980.

Filliozat, Jean, Religion, Philosophy, and Yoga. New Delhi: Motilal, 1991

, The Classical Doctrine of Indian Medicine. Delhi: Munshiram Manoharlal, 1964.

Flood, Gavin, 'Body, Breath and Representation in Saiva Tantrism', Paragrana: Internationale Zeitschrift fur Historische Anthropologie, XVIII, No. 1 (2009), p. 78-92. An Introduction to Hinduism. Cambridge: Cambridge University Press, 1996.

Gerow, E., 'Rasa as a Category of Literary Criticism', in R. van M. Baumer and J. R. Brandon, ed., Sanskrit Drama in Performance. Honolulu: University of Hawaii Press, 1981.

Ghosh, Manomohan, ed. and trans., The Natyasastra (two vols). Calcutta: Graanthalaya Private Ltd, 1967 (1951).

Kunjunni, Raja K., Kutiyattam: an Introduction. Delhi: Sangeet Natak Akademi, 1964.

McDaniel, June, 'Emotion in Bengali Religious Thought: Substance and Metaphor', in Emotions in Asian Thought, ed. Joel Marks and Roger T. Ames. Albany: SUNY Press, 1995, p. 39-63.

Mee, Erin B., Theatre of Roots: Redirecting the Modern Indian Stage. Calcutta: Seagull Books, 2008.

- ed., Drama Contemporary: India. Baltimore: Johns Hopkins University Press, 2001.

Oida, Yoshi, with Lorna Marshall, The Invisible Actor. London: Methuen. 1997.

- The Actor Adrift. London: Methuen, 1992.

Paulose, K. G., Kutiyattam Theatre. Kottayam: D.C. Books, 2006.

Prekumar, The Language of Kathakali: a Guide to Mudras. Allahabad: Kitabistan, 1948.

Rao, Maya Krishna, Khol Do, programme note for a performance sponsored by the Centre for Performance Research, Aberystwyth, Wales, UK, 1999.

programme note, Bharat Rang Mahotsav 2010. New Delhi: NSD, 2010, p. 156-7.

Richmond, Farley, Kutiyattam: Sanskrit Theater of Kerala. Ann Arbor: University of Michigan Press (CD ROM), 1999.

Richmond, Farley, Darius Swann, and Phillip Zarrilli, Indian Theatre: Traditions of Performance. Honolulu: University of Hawaii Press, 1990.

Singleton, Brian, 'Teyyateyyam: Resisting Interculturalism through Ritual Practice', Theatre Research International, XXII, No. 2, 1999, p. 162-9.

Singleton, Mark, Yoga Body: the Origins of Modern Posture Practice. Oxford University Press, 2010.

Solomon, Rakesh, 'Culture, Imperialism, and National Resistance: Performance in Colonial India', Theatre Journal, XLVI, 1994, p. 323-47.

- 'From Orientalist to Postcolonial Representations: a Critique of Indian Theatre Historiography from 1827 to the Present'. Theatre Research International, XXIX, No. 2, 2004. p. 111-27.

Van Erven, Eugene, The Playful Revolution: Theatre and Liberation in Asia. Bloomington: Indiana University Press, 1992. 
Varenne, Jean, Yoga and the Hindu Tradition. Chicago: University of Chicago Press, 1976.

Vatsyayan, Kapila, The Square and the Circle of the Indian Arts. Atlantic Highlands: Humanities Press, 1983.

Venu, G., Mudras in Kathakali: Notations of 373 Hand Gestures. Irinjalakuda: Natankairali, 1984.

- Production of a Play in Kutiyattam. Irinjalakuda: Natanakairali, 1989. , Into the World of Kutiyattam. Irinjalakuda: Natanakairali, 2002.

White, David Gordon, 'Yogic Rays: the Self-Externalization of the Yogi in Ritual, Narrative, and Philosophy', in Paragrana: Internationale Zeitschrift fur Historische Anthropologie, XVIII, No. 1, 2009, p. 64-77.

, The Alchemical Body: Siddha Traditions in Medieval India. Chicago: University of Chicago Press, 1996.
Zachariah, Mathew, and R. Sooryamoorthy, Science for Social Revolution? Achievements and Dilemmas of a Development Movement: the Kerala Sastra Sahitya Parishad. New Delhi: Vistaar Publications, 1994.

Zarrilli, Phillip, 'Case Study: Social Drama in Kerala, India: Staging the "Revolution",' in Theatre Histories: an Introduction. London: Routledge, 2006, p. 391-9. Kathakali Dance-Drama: Where Gods and Demons Come to Play. London: Routledge, 2000.

, 'When the Body Becomes All Eyes': Paradigms and Practices of Power in Kalarippayattu. New Delhi: Oxford University Press, 1998.

, The Kathakali Complex: Actor, Performance, Structure. New Delhi: Abhinav Publishers, 1984.

Zimmermann, Francis Susruta Samhita. Cikitsasthana, unpublished translation, 1986, p. xxiv, 38-49.

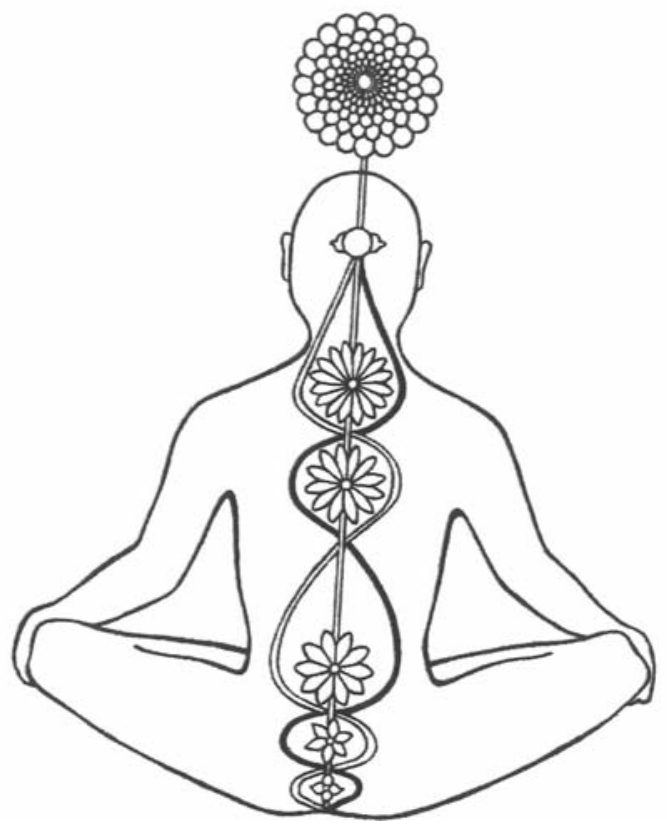

